\title{
Zebrafish Models of Photoreceptor Dysfunction and Degeneration
}

\author{
Nicole C. L. Noel ${ }^{1, *(\mathbb{D})}$, Ian M. MacDonald ${ }^{1,2}{ }^{\mathbb{D}}$ and W. Ted Allison ${ }^{1,3,4} \mathbb{D}$ \\ 1 Department of Medical Genetics, University of Alberta, Edmonton, AB T6G 2H7, Canada; \\ macdonal@ualberta.ca (I.M.M.); ted.allison@ualberta.ca (W.T.A.) \\ 2 Department of Ophthalmology and Visual Sciences, University of Alberta, Edmonton, AB T6G 2R7, Canada \\ 3 Department of Biological Sciences, University of Alberta, Edmonton, AB T6G 2E9, Canada \\ 4 Centre for Prions and Protein Folding Diseases, University of Alberta, Edmonton, AB T6G 2M8, Canada \\ * Correspondence: nnoel@ualberta.ca
}

check for

updates

Citation: Noel, N.C.L.;

MacDonald, I.M.; Allison, W.T.

Zebrafish Models of Photoreceptor

Dysfunction and Degeneration.

Biomolecules 2021, 11, 78. https://

doi.org/10.3390/biom11010078

Received: 19 December 2020

Accepted: 4 January 2021

Published: 9 January 2021

Publisher's Note: MDPI stays neutral with regard to jurisdictional clai$\mathrm{ms}$ in published maps and institutional affiliations.

Copyright: $\odot 2021$ by the authors. Licensee MDPI, Basel, Switzerland. This article is an open access article distributed under the terms and conditions of the Creative Commons Attribution (CC BY) license (https:// creativecommons.org/licenses/by/ $4.0 /)$.

\begin{abstract}
Zebrafish are an instrumental system for the generation of photoreceptor degeneration models, which can be utilized to determine underlying causes of photoreceptor dysfunction and death, and for the analysis of potential therapeutic compounds, as well as the characterization of regenerative responses. We review the wealth of information from existing zebrafish models of photoreceptor disease, specifically as they relate to currently accepted taxonomic classes of human rod and cone disease. We also highlight that rich, detailed information can be derived from studying photoreceptor development, structure, and function, including behavioural assessments and in vivo imaging of zebrafish. Zebrafish models are available for a diversity of photoreceptor diseases, including cone dystrophies, which are challenging to recapitulate in nocturnal mammalian systems. Newly discovered models of photoreceptor disease and drusenoid deposit formation may not only provide important insights into pathogenesis of disease, but also potential therapeutic approaches. Zebrafish have already shown their use in providing pre-clinical data prior to testing genetic therapies in clinical trials, such as antisense oligonucleotide therapy for Usher syndrome.
\end{abstract}

Keywords: Danio rerio; inherited photoreceptor disease; retinitis pigmentosa; Leber congenital amaurosis; cone-rod dystrophy; cone dystrophy; choroideremia; macular degeneration; retinal neovascularization; regeneration

\section{Introduction}

Vision is possible due to specialized light-detecting cells in the eye called photoreceptors. The degeneration of photoreceptors or the retinal pigment epithelium (RPE), essential retinal support cells, results in permanent vision loss and blindness. Photoreceptor diseases are extremely diverse, which creates challenges for development of treatments to prevent or reverse vision loss [1]. The zebrafish model provides opportunity to model diverse blinding diseases and elucidate therapeutic avenues. This review highlights the utility of zebrafish for modelling inherited photoreceptor disease by: (i) introducing photoreceptors and photoreceptor conditions with a genetic component, (ii) outlining zebrafish photoreceptor organization and tools to assess photoreceptor health, (iii) summarizing zebrafish models of photoreceptor disease, (iv) discussing how these models are informative for human disease, and (v) presenting the therapeutic contributions of these models. Ultimately, zebrafish provide a valuable platform for defining disease mechanisms and testing therapeutics that can be used in the clinic.

\section{Photoreceptors and Their Diseases}

Photoreceptors are sensory neurons responsible for converting light into signals that are transmitted to the brain for interpretation, allowing the perception of visual information. There are two types of retinal photoreceptors, named after their distinct morphologies: 
cones, which are maximally sensitive to particular wavelengths of light; and rods, which are extremely sensitive to low levels of light and can detect single photons. Cones allow for high-acuity daytime and colour vision, while rods facilitate vision under dim-light and night conditions. Rods and cones have an outer segment (OS), the light-sensitive part of the photoreceptor; an inner segment (IS), a specialized compartment packed with mitochondria that is connected to the OS by a structure called the connecting cilium (CC); a cell body; and a synaptic terminal, where downstream cells innervate the photoreceptors (Figure 1A). The OS is a modified cilium that is responsible for the photoreceptor namescones have a cone-shaped OS, while rods have a rod-shaped OS. The OS contains many membranous discs that are packed with opsin, the light-sensitive protein that triggers a signalling cascade, which results in signal transmission to downstream neurons. In cones, OS discs are contiguous with the plasma membrane, whereas rod OS discs are internalized within the plasma membrane.

A

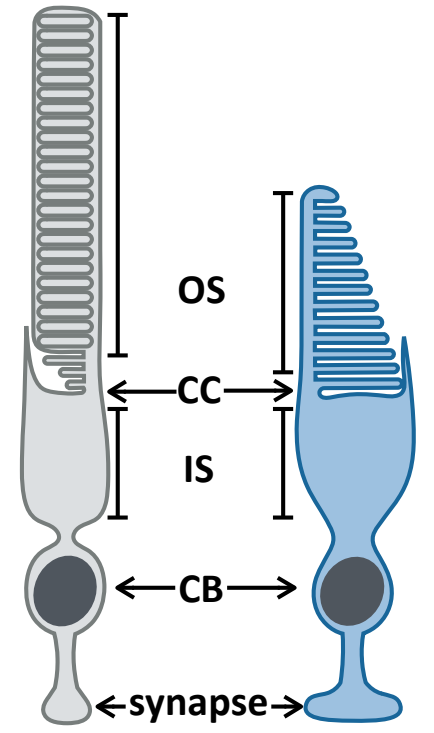

B

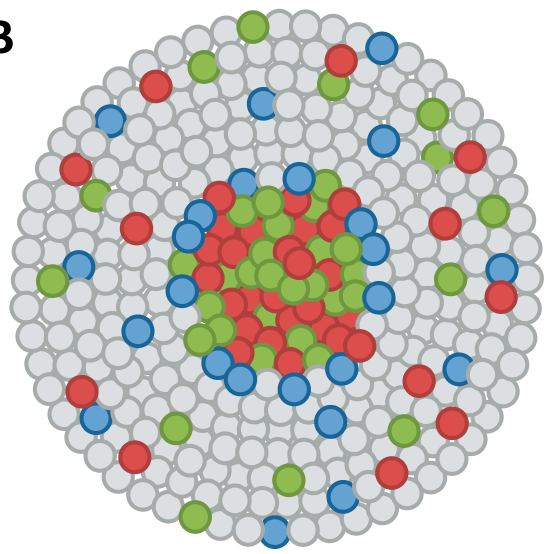

Figure 1. Anatomy of rod and cone photoreceptors and their organization in the human retina. (A) Cartoons of a rod (grey) and cone (blue) photoreceptor. Photoreceptors have an outer segment (OS) that is packed with light-sensitive opsin proteins, a connecting cilium (CC) that connects the OS with the mitochondria-rich inner segment (IS), a cell body (CB), and a synapse. (B) Cartoon of the human photoreceptor mosaic. Humans have three types of cones: red, green, and blue, depicted in those respective colours. The peripheral retina is rod-dense with cones interspersed throughout, while the central retina is cone-dense.

The human retina has three cone photoreceptor subtypes: blue light-sensitive (OPN1SW1), green light-sensitive (OPN1MW1), and red light-sensitive (OPN1LW1) cones [2,3]. The photoreceptors are organized such that the peripheral retina is rod-dense with cones interspersed throughout, and the central retina is cone-dense (Figure 1B) [4,5]. This cone-dense central region is called the macula, in the middle of which is a pit that contains exclusively cone photoreceptors, known as the fovea [6]. The fovea is important for high-acuity central vision. Fovea-like structures are rarely seen outside of primate species.

Photoreceptors are supported by the RPE. The RPE plays many essential roles in the retina, including maintenance of the blood-retina barrier, absorption of stray photons, transport of materials to and from the underlying choroid vessels, phagocytosis of shed photoreceptor OS fragments, and recycling of chromophores necessary for the visual cycle [7]. The RPE also secretes factors and signalling molecules important for photoreceptor function and neuroprotection, including pigment epithelium-derived factor (PEDF), which aids in photoreceptor survival [8-10]. 
Photoreceptor dysfunction and degeneration can be caused by mutations in many aspects of the photoreceptor cells, including structural factors, cilium components, phototransduction machinery, and ion channels [1]. In addition, RPE dysfunction leads to photoreceptor disease as the RPE has essential roles in photoreceptor maintenance and function. The complexities of photoreceptor development, function, and maintenances can result in extreme genetic and phenotypic heterogeneity for photoreceptor conditions. Moreover, photoreceptor disease can manifest as part of multi-system conditions, such as ciliopathies [11].

In the following sections, photoreceptor diseases with a genetic component are described. Inherited photoreceptor diseases cumulatively affect one in 2000 to one in 3000 individuals, and age-related macular degeneration, a multifactorial condition with a genetic component, is the leading cause of vision loss in the ageing population [12-14]. Vision loss has an immense impact on quality of life, and unfortunately these conditions have few effective therapies. This necessitates animal models of photoreceptor disease, as targeted therapeutics cannot be developed without an understanding of disease pathology and underlying mechanisms.

\subsection{Retinitis Pigmentosa}

Retinitis pigmentosa (RP) is a group of rod degenerative diseases, characterized by night blindness and peripheral vision loss. RP is the most common inherited photoreceptor condition, affecting one in 3500 to one in 5000 individuals. During RP progression, the RPE becomes degenerate and pigment granules can translocate into the retina, resulting in a feature called bone spicule. Cones are spared initially in RP, but eventually degenerate, leading to total blindness. Over 70 genes have been associated with RP, and RP can be inherited in an autosomal recessive, dominant, X-linked, digenic, or mitochondrial manner [1]. Additionally, RP can be caused by mutations that directly affect the rod photoreceptors or the RPE. RP can manifest alone or in combination with extraocular phenotypes in syndromes.

\subsection{Leber Congenital Amaurosis}

Leber congenital amaurosis (LCA) is a severe, early-onset disease of the RPE and photoreceptors. LCA is caused by mutations in essential RPE and photoreceptor genes. The genes most commonly mutated in LCA patients are RPE65, GUCY2D, and CEP290 [15-18]. The RPE65 gene produces an RPE-specific retinoid isomerohydrolase, which is essential for recycling of components required for the photortransduction cascade [19]. GUCY2D produces the protein retinal guanylate cyclase-1 (RETGC1), which is also needed for phototransduction [20,21]. CEP290 encodes a centrosomal protein important for development of the centrosome and cilium [22].

\subsection{Choroideremia}

Choroideremia is an X-linked condition characterized by degeneration of the photoreceptors, RPE, and underlying choroid vasculature. Choroideremia is caused predominantly by mutations in the gene CHM, which encodes the protein REP1 [23]. REP1 posttranslationally modifies Rab proteins, which are essential for Rab protein function. Defects in Rab protein function would impact processes in many retinal cell types, but there is evidence from animal models that the RPE defects lead to photoreceptor degeneration when REP1 is lost [24,25].

\subsection{Cone-Rod Dystrophy}

Cone-rod dystrophies (CORD) are conditions where both the cones and rods are affected. CORD patients can present with visual acuity loss, light sensitivity, colour vision defects, central vision loss, and partial peripheral vision loss. 


\subsection{Enhanced S-cone Syndrome}

Enhanced S-cone syndrome is a unique condition, as it presents with increased photoreceptor function. Enhanced S-cone syndrome is caused by mutations in the transcription factors NR2E3 or NRL, which are required for rod development [26-29]. Patients with enhanced S-cone syndrome therefore have cone-only retinas with enhanced blue cone sensitivity and experience night blindness and photoreceptor degeneration [26].

\subsection{Cone Dystrophy}

Cone dystrophies are conditions that affect the cone photoreceptors, leading to their dysfunction and degeneration. Cone dystrophies typically present with visual acuity defects, colour vision abnormalities, and reduced cone responses, measured by electroretinography (ERG). Although extremely rare, there are reported cases of peripheral cone dystrophies, whereby the cones in the peripheral retina are more affected than those in the central macula [30].

Macular degenerations involve loss of cones in the macula and leads to visual acuity decline, colour vision disturbances, and central vision loss. Cone loss can result in macular atrophy, which is visible on routine fundoscopy imaging. There are many different types of macular degeneration, the most common of which is age-related macular degeneration (AMD).

AMD is the leading cause of vision loss in the ageing population [12]. AMD is a multifactorial condition, and a combination of genetic and environmental factors influence a person's likelihood of developing AMD. There are two forms of AMD: dry and wet. Dry AMD is the most common, characterized by geographic atrophy that results from the degeneration of RPE, photoreceptors, and choroid vessels. Dry AMD can progress to wet AMD, which is characterized by choroidal neovascularization. The aberrant vessels are fragile and prone to leaking or bursting, which can lead to fluid buildup and retinal scarring. Lipid deposits, called drusen and subretinal drusenoid deposits, are hallmark features of AMD. Drusen develop between the RPE and underlying choroid vasculature, while subretinal drusenoid deposits occur between the photoreceptor OSs and RPE. Although characteristic features of AMD, the impact that drusen and subretinal drusenoid deposits have on the retina and photoreceptor biology is unclear.

\subsection{Achromatopsia}

Achromatopsia is a condition characterized by lack of colour vision. Achromatopsia can either be complete or incomplete; individuals with complete achromatopisa have no functioning cone photoreceptors, while those with incomplete achromatopsia have partial cone function. Achromatopsia is generally caused by mutations in cone-specific phototransduction machinery or ion channels that prevent the cones from relaying messages to downstream neurons $[1,31]$.

\section{Zebrafish as a Model for Photoreceptor Disease: Photoreceptor Features, Function and Morphological Assessment, and Model Generation}

Zebrafish are a powerful model for photoreceptor development and disease. The zebrafish retina is remarkably conserved to the mammalian retina in terms of development, structure, and function. Researchers can study cone photoreceptor development and disease in zebrafish, which is challenging in nocturnal rodent models. There are many tools for assessing zebrafish visual responses, photoreceptor function, and morphology in live animals. Additionally, there are well-established technologies for generating transgenic and mutant animals. These features are outlined below. For reviews that compare retinal features of different animal species used to model disease, see [32,33].

\subsection{The Zebrafish Visual System}

Zebrafish have a visual system that develops rapidly and larval zebrafish can be assessed for visual function at early ages. Zebrafish embryos develop externally and embryos are transparent, meaning that visual system development can be easily observed. 
Eye field patterning begins at $28 \mathrm{~h}$ post fertilization (hpf), and the developing retina expresses opsin genes as early as $51 \mathrm{hpf}[34,35]$. At 5 days post fertilization (dpf), zebrafish can carry out complex visually-mediated behaviours such as prey capture [36], meaning that larvae can be assessed for visual defects very early in life.

The zebrafish retina is cone-rich, similar to the human macula. This is a huge benefit since other commonly used models, such as mice and rats, are nocturnal with few cones and no macula-like region. The abundance of cone photoreceptors allows for modeling of cone diseases in zebrafish. However, there are nevertheless notable differences between zebrafish and humans. Zebrafish have double cones, which are not observed in the mammalian retina. Additionally, the zebrafish photoreceptor mosaic is organized differently than the human mosaic, and while it can model general cone dystrophies, cannot accurately recapitulate macular degeneration. Although zebrafish have uneven distributions of cones at some stages, their retina does not have a macular region with increased cones and a central cone-only foveal pit [37]. It is important to note that although zebrafish do not have a retinal region that is structurally similar to the fovea, larvae do have a region that is important for high-acuity vision and is therefore functionally similar to the human fovea [38].

The zebrafish photoreceptor mosaic is differentially organized between larval and adult stages. Zebrafish have four cone subtypes: ultraviolet (sws1, homolog of mammalian OPN1SW), blue (sws2), green ( $r h 2)$, and red (lws, homolog of mammalian OPN1MW and OPN1LW). The green and red cones exist as physically fused double cones. Larval zebrafish have a cone-dominant retina with few rods [37,39]. As the larval zebrafish age, they develop more rods, and in adulthood there are roughly equal proportions of cones and rods [37]. Adult zebrafish photoreceptors are organized into a highly structured a row mosaic, with UV and blue cones alternating in their rows, and red and green cones alternating in neighbouring rows [37,40] (Figure 2A,B). Some opsins have multiple copies that are differentially expressed according to retinal location and age. For example, zebrafish have four green opsin genes ( $r h 2-1, r h 2-2, r h 2-3$, and $r h 2-4)$, two red opsin genes (lws 1 and lws2), and two rhodopsin genes (rho and $r h o l)$, which have different spatial localizations depending on developmental stage [41-43]. There are many tools available for visualizing zebrafish photoreceptors, including transgenic lines expressing fluorescent proteins in specific cell types and antibodies for immunolabelling (Figure 2B,C). A subset of commonly used transgenic lines (Table 1) and antibodies (Table 2) are highlighted here; available zebrafish tools are catalogued on the Zebrafish Information Network (ZFIN) [44]. The well-characterized promoters in these transgenes can also be utilized to drive expression of other genes, such as disease or cell death genes. 

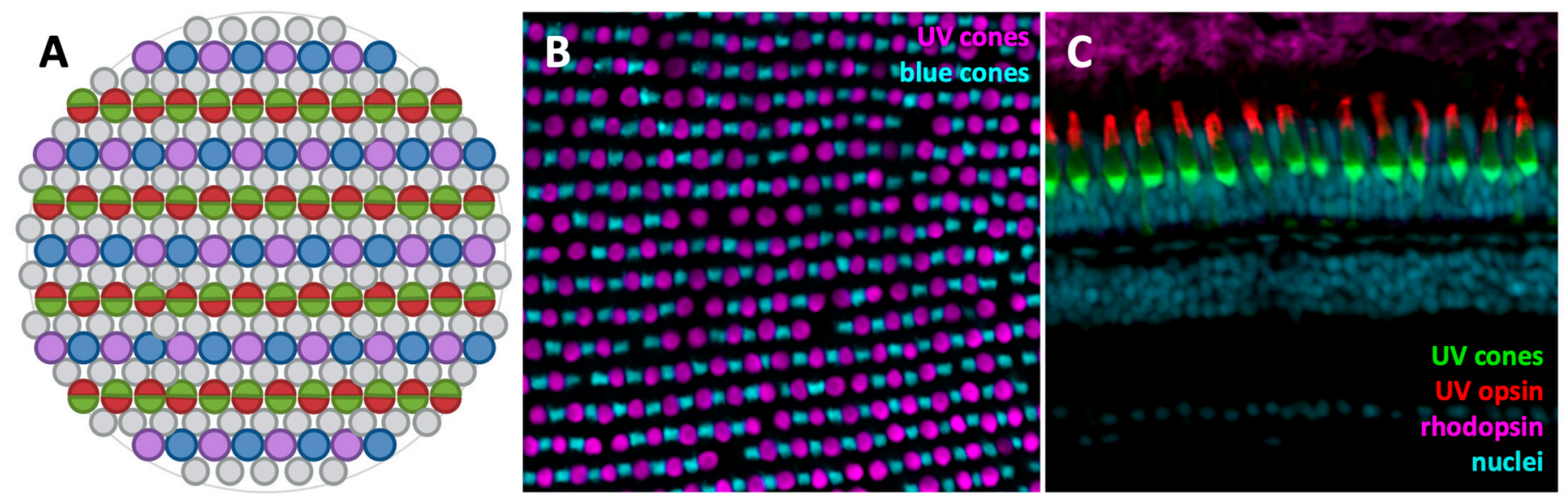

Figure 2. Zebrafish photoreceptor organization. (A) Cartoon depiction of the adult zebrafish photoreceptor mosaic. UV and blue cones, depicted in purple and blue respectively, alternate in their rows while red and green double cones alternate in neighbouring rows. Rods are studded throughout. (B) Fluorescent image of a flat-mounted adult transgenic zebrafish retina, with GFP expressed in UV cones (magenta) and mCherry expressed in blue cones (cyan). The alternation of UV and blue cones in their rows is apparent. (C) Immunofluorescent image of a cryosectioned adult $\operatorname{Tg}($ sws1:GFP) zebrafish retina with GFP in UV cones (green). UV opsin (red) and rhodopsin (magenta) are labelled, as well as nuclei (cyan).

Table 1. Examples of common zebrafish transgenic lines with labelled photoreceptors.

\begin{tabular}{ccc}
\hline Transgene & Description & Reference \\
\hline $\operatorname{Tg}(3.2 g n a t 2: e G F P)$ & Enhanced GFP expressed in all cone photoreceptors & {$[45]$} \\
$\operatorname{Tg}($ rho:eGFP $)$ & Enhanced GFP expressed in rod photoreceptors & {$[46]$} \\
$\operatorname{Tg}($ sws $: G F P)$ & GFP expressed in UV cones & {$[47]$} \\
$\operatorname{Tg}($ sws2:mCherry $)$ & mCherry expressed in blue cones & {$[48]$} \\
\hline
\end{tabular}

Table 2. Examples of commonly used antibodies that label zebrafish photoreceptors.

\begin{tabular}{cccc}
\hline Antibody & Antigen & Labels & Reference \\
\hline 4 c12 & N/A & Rods & {$[49]$} \\
10c9.1 & UV opsin & UV cone OSs & {$[50]$} \\
1D4 & Red opsin & Red cone OSs & {$[51]$} \\
zpr1 & Arrestin3a & Red/green double cones & {$[52,53]$} \\
zpr3 & N/A & Rod and double cone OSs & {$[54]$} \\
\hline
\end{tabular}

\subsection{Visually-Mediated Responses as Diagnostics in Zebrafish}

Visual function can be investigated in zebrafish larvae by several behavioural tests. Visually-mediated responses in zebrafish larvae include the optokinetic response (OKR), optomotor response (OMR), and visual motor response (VMR). OKR tracks the eye movements of the larvae in response to visual stimuli. OKR involves immobilizing a larvae and placing the animal inside of a drum with moving black and white stripes [55-58]. As the drum moves, the zebrafish's eyes will track the movement then saccade back to the origin [55-58]. OKR can be detected as early as $3 \mathrm{dpf}[57,58]$. OMR uses a visual stimulus to elicit a swim response. Larvae are placed inside narrow tracks on top of a flat screen [58-60], a stimulus of moving lines plays on the screen, and the fish swim in the direction of the moving stimulus [58,59]. OMR is detectable as early as $4 \mathrm{dpf}$, but is more robust at 6-7 dpf [59]. VMR is a visually-mediated startle response triggered by rapid changes in light. Individual larvae are placed into wells of a 96-well plate and then the plate is inserted into a recording chamber with lights that can be turned on and off [61]. Larvae will become active when the lights come on, followed by returned to baseline; 
similarly, when the lights are turned off, there is an increase in activity followed by a return to baseline. VMR can be elicited from larvae as early as $4 \mathrm{dpf}$.

\subsection{Retinal Imaging and Functional Assessement for Zebrafish}

Zebrafish have many tools available for the assessment of photoreceptor health in live animals. These techniques include optical coherence tomography (OCT), ERG, calcium imaging, and fundoscopy.

OCT is a live imaging technique that uses the differential reflectivity of the various retinal cell types to capture images of the retinal layers and photoreceptor mosaic. Photoreceptor ISs are highly reflective due to the abundance of densely packed mitochondria, thereby facilitating visualization of the photoreceptor layer [62]. Refractive properties of the zebrafish lens cause zebrafish OCT to be very high resolution, and individual photoreceptor ISs can be observed [63,64]. En face projections provide a view of the photoreceptor mosaic.

Electroretinography is an electrophysiological method for assessing retinal function. ERG involves placing an electrode on the subject and using light stimuli to elicit a response. The testing conditions and light stimuli can be modified to assess specific photoreceptor types. ERG has been utilized to assess both larval and adult zebrafish [65-69]. Calcium imaging techniques can also be used to assess photoreceptor activity in transgenic zebrafish larvae expressing a $\mathrm{Ca}^{2+}$ sensor fused to a fluorescent protein [70,71]. When $\mathrm{Ca}^{2+}$ is present in the cell, such as during neuronal activity, the protein undergoes a conformational change that increases fluorescence [72,73]. This is a useful tool to assess whether photoreceptor cells are responding to stimuli, although it cannot easily be used in live adult zebrafish due to eye size and significant pigmentation.

Fundoscopy involves shining a light into the eye to observe the back of the eye, termed the fundus. Zebrafish fundoscopy enables visualization of adult zebrafish retinal cells in transgenic animals expressing fluorescent proteins [48]. This can be used to observe progressive photoreceptor degeneration and regeneration.

\subsection{Generation of Transgenics and Mutants}

External fertilization and large clutch size mean that zebrafish embryos are very accessible. This makes generation of transgenic or mutant animals straightforward, as constructs can be injected directly into the single-cell embryo [74]. The generation of transgenic zebrafish can be accomplished using transposase and Tol2 transposable element sites or I-SceI meganuclease [75-77]. However, some transgene sequences are susceptible to silencing in zebrafish. The Gal4/UAS transcriptional activation system is a gene/enhancer trap system; the zebrafish-adapted version is KalTA4/UAS [78]. This involves the tissue-specific activation of the KalTA4 transcription factor, which then recognizes the UAS promoter and drives expression of the downstream transgene-for example, a fluorescent protein. Unfortunately, the UAS promoter becomes silenced throughout subsequent generations, and silencing can even be observed in individual fish; larvae may have high levels of expression, but expression can decrease drastically in adulthood due to silencing $[79,80]$. However, silencing seems to be a relatively uncommon occurrence when transgenes are generated using endogenous zebrafish promoter sequences. Promoter silencing has also created challenges for generation of conditional knockout lines in zebrafish. Cre-lox recombination utilizes Cre recombinase and lox target sites to create conditional loss-of-function alleles. Cre can be expressed ubiquitously or under tissue-specific promoters. Cre-lox has been successfully utilized in zebrafish and there are increasing numbers of tools and zebrafish Cre-driver lines [81-86]. However, it has been difficult to find tissue-specific promoters that are not silenced over time, as well as issues activating inducible Cre in zebrafish. In addition, it is challenging to insert lox sites around target genes. As a result, conditional knockout zebrafish are difficult to generate and rare.

There are many means by which mutations have been introduced to zebrafish, including in forward genetic screens using mutagens such as ethylnitrosourea, or tar- 
geted gene mutations with zinc finger nucleases (ZFNs), transcription activator-like effector nucleases (TALENs), and clustered regularly interspaced short palindromic repeats (CRISPR)/Cas [87-90]. However, mutants isolated from forward genetics screens require extensive mapping in order to locate the affected gene(s), and some lines never had a mutated gene identified. ZFN and TALEN editing strategies require fusing a nuclease to a sequence-specific DNA binding domain to target genomic regions; this process can therefore be strenuous, but resulting mutants are unlikely to have off-target mutations introduced. CRISPR/Cas systems are easily adaptable to different target genes, but off-target cutting is difficult to predict, though there are methodologies that help limit off-target mutagenesis [91-94]. There are nevertheless challenges associated with the zebrafish genome. The teleost lineage underwent a genome duplication event, meaning that many genes have two copies. This creates complexities when making mutants, and functional redundancy between the paralogs can necessitate generation of double mutants. Conversely, there can be sub-specialization of the paralogs. It is not uncommon for one gene to be specific to cones while the other is either specific to rods, have pan-photoreceptor expression, or be expressed elsewhere in the retina or nervous system entirely [95-98].

\subsection{Regenerative Response}

The mature human retina has very limited capacity to replace lost neurons, meaning that loss of any retinal neurons is irreversible and can lead to vision impairment. Conversely, zebrafish retinas have a robust regenerative capacity [99]. This is both a benefit and challenge, as it permits investigation into mechanisms of neuronal regeneration, but also means that the zebrafish retina responds differently to acute retinal lesions than the human system. Assessment of disease progression can be complicated by regeneration of lost photoreceptors; there may be cases where degeneration is underestimated due to regenerated photoreceptors restoring visual function. It is important for researchers to be aware of how regenerative responses may affect their assessment of retinal damage longitudinally. However, factors necessary for regenerative responses can be pharmacologically blocked or knocked down to allow for disease progression more comparable to humans [100-102], although blocking regeneration may cause additional issues with retinal biology. Potential regenerative responses are important to be aware of when investigating models for potential degeneration. Mechanisms underlying the zebrafish retinal regenerative response will be discussed further in Section 5.3.

\section{Zebrafish Models of Photoreceptor Disease}

There are many zebrafish models of photoreceptor disease, including models where degeneration is induced by exposure to light or toxins, transgenic lines expressing deleterious components, and mutants, which are reviewed here.

\subsection{Light Ablation}

Light ablation allows for photoreceptor ablation while the remaining neural retina stays relatively intact [99]. There are also differences in susceptibility of photoreceptor types depending on retina location, potentially due to the amount of light that reaches specific areas [103-107]. Light ablation typically causes generalized destruction of the photoreceptors, though targeted laser ablation can be performed to target specific photoreceptor types [108]. A robust regenerative response occurs post light ablation [109].

\subsection{Toxic Lesions}

\subsubsection{Ouabain}

Retinal lesion can be achieved with injection of ouabain, which inhibits $\mathrm{Na}^{+} / \mathrm{K}^{+}$ ATPase and thereby reduces available ATP for cellular processes [110]. Dosage determines the retinal layers that are affected. High doses can penetrate far into the retina, damaging many retinal cell types including photoreceptors, while lower doses only reach inner retinal layers [110-112]. This method cannot easily be limited to only one cell type, although 
ouabain could be injected subretinally to cause more targeted photoreceptor and RPE damage. In zebrafish, ouabain has been used successfully to ablate retinal neurons, including photoreceptors, and the resultant damage stimulates a regenerative response [111].

\subsection{2. $\mathrm{N}$-Methyl- $\mathrm{N}$-nitrosourea}

$\mathrm{N}$-methyl- $\mathrm{N}$-nitrosourea (MNU) is an alkylating agent that transfers its methyl group to nucleic acids, resulting in DNA mutations and damage. It is a carcinogen, typically used to induce tumours in cancer models $[113,114]$. MNU treatment in animals induces photoreceptor cell death, presumably through DNA damage [115-117]. MNU treatment primarily affects the rod photoreceptors and therefore produces rod degeneration akin to RP [115]. The acute loss of rods results in a regenerative response in zebrafish [115]. Why MNU treatment is more damaging to rods than cones is unknown.

\subsection{Hypoxia-Induced Neovascularization}

Exposing adult zebrafish to a hypoxic environment results in retinal neovascularization [118]. Angiogenic sprouts being to grow around day 2 and continue to grow throughout hypoxia treatment. Similar to wet AMD neovascularization, the aberrant vessel growth can be minimalized with anti-VEGF treatment. How the neovascularization impacts retina function in adult zebrafish is poorly investigated.

\subsection{Gene Knockdown (Morpholinos)}

Morpholinos are antisense oligonucleotide analogs, usually 20-25 bases in length, which complement and bind mRNA to prevent the production of protein products. Morpholinos can either block mRNA splicing or translation $[119,120]$. They can be easily introduced to zebrafish embryos by microinjection at the single-cell stage [119]. However, morpholinos can have off-target effects and morpholino experiments need to be carefully controlled. It has been reported that morpholino phenotypes are often not recapitulated in genetic mutants [121]; the reason for this is unclear, but may be due lack of genetic compensation. When there are genomic mutations, there is genetic compensation in response to the genetic lesions. However, this compensation does not occur in a gene knockdown scenario [122]. Despite their limitations, morpholinos provide the opportunity for preliminary assessment of potential gene function when properly controlled, which is extremely valuable for expeditious assessment of putative disease-causing genes.

\subsection{Transgenic Models}

\subsubsection{XOPS:mCFP}

The $\operatorname{Tg}(X O P S: m C F P)$ transgenic zebrafish line expresses membrane-targeted cyan fluorescent protein (mCFP) under the Xenopus rhodopsin promoter (XOPS) [123] (Table 3). The $\mathrm{mCFP}$ is overexpressed, resulting in toxicity and rod degeneration. Interestingly, there is no sign of cone death, despite rod loss. This differs from what is observed in humans with RP, where cone degeneration follows rod death. The reason for cone persistence despite rod degeneration in the $\operatorname{Tg}(X O P S: m C F P)$ zebrafish is unclear, though could be due to the cone-rich environment of the zebrafish retina, compared to the rod-rich human retina. The phenomenon of cone survival in zebrafish provides opportunities to investigate how cone photoreceptors respond to rod loss, and may provide insight into factors contributing to cone death in human RP.

\subsubsection{Nitroreductase Ablation}

Nitroreductase (NTR, $n f s B$ gene) is a bacterial enzyme that can reduce otherwise inert prodrugs, such as metronidazole (MTZ) into DNA cross-linking agents, allowing for the targeted ablation of cells expressing NTR [124]. Importantly, there appears to be no toxic bystander effects as the result of NTR ablation, and neighbouring (non-NTR expressing) cells are not damaged by the treatment $[60,124-126]$. The NTR mechanism of ablation is thus one of the few methods that allows for ablation of targeted cell subtypes. Additionally, 
as NTR-fluorescent protein fusions have been made, the degeneration of target cells can be followed, and, where possible, regeneration of these cells can also be observed. It is also possible to delay, or prevent, the regeneration of the target cell type by continued treatment with MTZ, since regenerating cells will undergo apoptosis once they begin to express NTR.

The NTR method has been used to ablate UV, blue, and red cones as well as rods in zebrafish [60,125-128]. Intriguingly, ablation of specific photoreceptor subtypes has revealed thresholds for triggering regenerative responses. In larval zebrafish, NTR-mediated blue cone ablation did not stimulate appreciable amounts of regeneration [127]. However, simultaneously ablating both blue and red cones using the NTR mechanism successfully induced robust regeneration. Conversely, ablating solely UV or red cones successfully stimulated a regenerative response [125,127,129]. Regenerated cones can be of multiple subtypes, and are not restricted to the ablated cone subtype [129]. How NTR ablation of specific cone subtypes triggers regenerative responses in the adult zebrafish retina has not been investigated. The ablation of rods in the adult zebrafish retina demonstrated that there is similarly a threshold of damage that needs to be reached to trigger regenerative responses. Ablating the vast majority of rod photoreceptors stimulated a regenerative response, but incomplete ablation of rods did not [126].

NTR ablation of RPE resulted in RPE degeneration as well as subsequent photoreceptor degeneration [130]. RPE loss by this method triggered a regenerative response, and animals were able to re-establish an RPE monolayer. While regenerative capacity for retinal neurons in zebrafish is well established, this was the first study to show RPE regeneration post degeneration.

\subsubsection{Disease Genes}

Transgenesis technology allows for insertion of a disease-causing gene from humans or other species into the zebrafish genome. This can be used to generate models of photoreceptor disease, as well as investigate how the mutated protein behaves within and impacts photoreceptor cells.

There are several transgenic zebrafish models of RP-like photoreceptor disease (Table 3). Zebrafish with transgenically introduced mouse rhodopsin with a common RP mutation [131-133], Tg(rho:msRho-P23H-flag), have notable rod loss by early adulthood [134]. Similarly, a line expressing human rhodopsin with the RP-causing Q344X mutation in rod photoreceptors, $\mathrm{Tg}(r h o: h s a R H O-Q 344 X)$, has rapid rod degeneration [135,136]. Adcy is an enzyme normally found in the IS that is related to mechanisms of photoreceptor cell death; antagonists of Adcy increase photoreceptor survival in degeneration models [136]. An RP-like transgenic line that expresses Adcy2b with a C-terminal rhodopsin tail, targeting the protein to the OS, undergoes rod degeneration [136]. PRPF31 is involved in splicing of pre-mRNA and has been associated with RP [137]. Tg(rho:prpf3-AD5-mCherry) zebrafish express mutant prpf31 in rods and have abnormal splicing for a subset of important photoreceptor genes and increased cell death in the photoreceptor layer [138]. A single nucleotide polymorphism in the HTRA1 promoter region increases an individual's likelihood of developing AMD $[139,140]$. Overexpression of HTRA1 in mouse RPE has also been reported to induce choroidal neovascularization, similar to what is observed in AMD [141]. Zebrafish larvae transgenically expressing human HTRA1 in rod photoreceptors have rod cell death [142]. Of interest, the zebrafish model of RP expressing human mutant rhodopsin have increased htra1a expression [142].

There is a transgenic cone-rod dystrophy model with mutant human GUCY2D, which produces the protein retinal guanylate cyclase-1 (RETGC1) [143] (Table 3). Cones degenerate in larval zebrafish, followed by rod degeneration. In early adulthood, rods look dysmorphic, but whether rods continue to degenerate in aged adult retina has not been reported. 
Table 3. Transgenic zebrafish models of photoreceptor disease.

\begin{tabular}{|c|c|c|c|}
\hline Photoreceptor Disease & Transgene & Photoreceptor Features & Reference \\
\hline Cone-rod dystrophy & $\begin{array}{c}\operatorname{Tg}(3.2 g n a t 2: h s a . G U C Y 2 D-E 837 D \\
\text { R838S) }\end{array}$ & $\begin{array}{c}\text { Dysmorphic cones at } 5 \mathrm{dpf} \text {. 3-month-old animals have a } \\
\text { thin photoreceptor layer in the central retina, } \\
\text { dysmorphic cones, and less cone and rod staining }\end{array}$ & [143] \\
\hline Retinitis & $\operatorname{Tg}(r h o: h s a R H O-Q 344 X)$ & Rod degeneration detectable at $5 \mathrm{dpf}$, rapid progression. & [136] \\
\hline Retin & $\operatorname{Tg}($ rho:msRho-P23H-flag) & Rod degeneration at 3 months. & [134] \\
\hline mentosa & $\operatorname{Tg}$ (rho:prpf3-AD5-mCherry) & Increased photoreceptor cell death at 5 months. & [138] \\
\hline Retinitis pigmentosa & $\operatorname{Tg}($ rho:adcy $2 b-r h o-t a i l)$ & Rod degeneration noted at $14 \mathrm{dpf}$. & [136] \\
\hline Retinitis pigmentosa & $\operatorname{Tg}($ rho:hsaHTRA1) & Rod degeneration at $5 \mathrm{dpf}$. & [142] \\
\hline Retinitis pigmentosa & $\operatorname{Tg}(X O P S: m C F P)$ & $\begin{array}{c}\text { Rapid rod degeneration by } 5 \mathrm{dpf} \text {. Adults do not have a } \\
\text { rod response on ERG. }\end{array}$ & [123] \\
\hline
\end{tabular}

\subsection{Genetic Mutants}

Genetic screens and genome editing strategies have fostered the discovery and generation of many zebrafish mutants with photoreceptor phenotypes. Of note, there are instances where the disease phenotype in zebrafish differs from what is observed in human patients with mutations in the same gene. This phenomenon may be due to disparities in the type of genetic lesions present. Loss-of-function mutations are most commonly engineered in animal models, but disease-causing mutations observed in humans may instead be missense, splice site mutations, or compound. Alternatively, these divergences could be related to gene duplication and subspecialization/neospecialization in zebrafish, or differences between the human and zebrafish photoreceptor mosaic.

Mutations in genes affecting cilia or other proteins expressed in many tissue and cell types may have extraretinal phenotypes and early lethality. Only the photoreceptor phenotypes will be focused on here. For previous reviews on zebrafish models of ocular disease, please see [144-148].

Please note that the zebrafish mutants are categorized based on the condition that their phenotype is most similar to, and this may not necessarily align with the phenotypes observed in human patients with mutations in the same gene. In order to be included here, the zebrafish mutant lines had to have an identified mutated gene and present with photoreceptor degeneration, photoreceptor dysfunction, or otherwise fit into a photoreceptor condition category based on retinal findings.

\subsubsection{Retinitis Pigmentosa}

Mutations in the rod-specific opsin gene, rhodopsin (RHO), are a frequent cause of RP [131-133,149]. Recently, several rho mutant zebrafish lines have been generated which model dominant or recessive RP $[150,151]$ (Table 4; see for list of zebrafish mutant RP models). These animals have rod degeneration beginning soon after rod development and continuing into adulthood [150,151]. Cones are unaffected in rho mutants.

RP2 is a cilium-associated protein and its mutation causes X-linked RP [152-155]. Knockout of $r p 2$ in zebrafish results in photoreceptor functional defects in larval animals, as well as progressive rod OS degeneration, followed by cone OS degeneration [156]. Mutations in CERKL, a gene involved in metabolism of components important for neuron survival, can cause RP [157]. Zebrafish cerkl knockout larvae have photoreceptor defects detected by electrophysiological assessment [158]. Young adults have OS defects, primarily affecting the rods, which progress to rod degeneration and eventual cone OS defects. $K I F 3 B$ encodes a kinesin motor involved in transport through the cilium and mutations in KIF3B have recently been associated with a ciliopathy that presents with RP [159]. kif3b mutant zebrafish have rapid rod degeneration and delayed OS genesis, but cones appear normal $[160,161]$. RPGRIP1 localizes to the CC and OS and mutations in RPGRIP1 cause several different photoreceptor diseases, including LCA, RP, and CORD [162-165]. Zebrafish rpgrip1 mutants do not have proper rod OS development, and none are observed at $5 \mathrm{dpf}$ [166]. Rod cells were almost entirely absent by 3 months of age. Cones appear normal at $7 \mathrm{dpf}$, but have functional defects and cone degeneration is clear by 6 months. By 23 months, almost all photoreceptors are lost. Interestingly, double cones degenerate 
before single cones. RP1L1 is a photoreceptor cilium-associated protein, mutations in which lead to RP and macular degeneration [167-169]. Mutant rp1l1 zebrafish have rod functional defects at 6 months, which worsen over time [170]. By 12 months, animals have disorganized rod OSs, rod loss, and subretinal drusenoid deposits [170].

MYO7A encodes a myosin protein expressed in human photoreceptors and RPE [171]. MYO7A mutations lead to a subtype of Usher syndrome, a condition characterized by hearing and vision loss $[172,173]$. myo7aa mutant larvae have decreased photoreceptor function and rod photoreceptor loss [174]. Mutations in USH2A also cause a subtype of Usher syndrome [175]. USH2A encodes the transmembrane protein usherin, the exact function of which is unknown $[175,176]$. ush $2 a$ mutant zebrafish have photoreceptor functional defects in larvae, and progressive photoreceptor degeneration in adulthood [177,178]. Rods begin to degenerate prior to cone degeneration [177].

her9 is a transcriptional regulator that has increased expression in $\operatorname{Tg}(X O P S: m C F P)$ retinas undergoing rod degeneration [179]. her9 mutant larvae have a lower abundance of rods and there is evidence that red cones do not develop appropriately or rapidly degenerate [180]. After rods begin to decrease in number, green cones are reduced in number and appear to have small OSs, while blue and UV cones appear unaffected. Animals do not survive past $13 \mathrm{dpf}$. her 9 orthologs have not been associated with human photoreceptor disease.

Table 4. Zebrafish mutant models of retinitis pigmentosa-like photoreceptor disease.

\begin{tabular}{|c|c|c|}
\hline Gene & Photoreceptor Features & Reference \\
\hline cerkl & $\begin{array}{l}\text { Photoreceptor functional defects at } 7 \mathrm{dpf} \text {. Rod OS defects at } 3 \text { months, cone OS defects at } 7 \\
\text { months. Notable thinning of the photoreceptor layer and cell death by } 12 \text { months. }\end{array}$ & [158] \\
\hline her9 & Decrease in rod photoreceptors at $5 \mathrm{dpf}$. Few double cones with short OSs at $12 \mathrm{dpf}$. & [180] \\
\hline kif $3 b$ & Delayed OS development. Rapid rod degeneration by $5 \mathrm{dpf}$. & {$[160,161]$} \\
\hline myo7aa & Decreased photoreceptor function at $5 \mathrm{dpf}$. Reduced rods at $8 \mathrm{dpf}$. & {$[174]$} \\
\hline rho & Rod loss observed at $6 \mathrm{dpf}$. Degeneration continues into adulthood. & {$[150,151]$} \\
\hline rp1l1 & $\begin{array}{c}\text { Rod dysfunction at } 6 \text { months. Subretinal drusenoid deposits at } 11 \text { months. Photoreceptor loss } \\
\text { observed at } 12 \text { months. }\end{array}$ & [170] \\
\hline$r p 2$ & $\begin{array}{l}\text { Photoreceptor functional defects at } 7 \mathrm{dpf} \text {. Short rod OSs at } 2 \text { months; cone OS defects at } 4 \\
\text { months; significant rod OS loss and decreased cone OSs by } 7 \text { months. }\end{array}$ & [156] \\
\hline rpgrip1 & $\begin{array}{l}\text { No rod OSs at } 5 \mathrm{dpf} \text {. Cone dysfunction at } 7 \mathrm{dpf} \text {. Severe rod degeneration by } 3 \text { months, } \\
\text { followed by cone degeneration. By } 23 \text { months, majority of photoreceptors have degenerated. }\end{array}$ & [166] \\
\hline$u \operatorname{sh} 2 a$ & $\begin{array}{l}\text { Decreased photoreceptor function at } 5-7 \mathrm{dpf} \text { and increased photoreceptor apoptosis at } 8 \mathrm{dpf} \text {. } \\
\text { Notable rod OS degeneration at } 12 \text { months, cone OS degeneration observed at } 20 \text { months. }\end{array}$ & {$[177,178]$} \\
\hline
\end{tabular}

\subsubsection{Leber Congenital Amaurosis}

Mutations in genes involved in ciliogenesis initiation, cilia elongation, transport of cilium components, or physiological processes can result in LCA or an LCA-like phenotype in animal models. Intraflagellar transport (IFT) proteins play crucial roles in movement of cargo in the cilium, which can be facilitated by kinesin motors. ift88 and ift172 zebrafish mutants have no photoreceptor OS development and the photoreceptors degenerate [181-184] (see Table 5 for list of zebrafish mutant LCA models). Sensory cilia in general do not develop in these animals [183]. Similarly, cluap1 (also known as ift28) mutant zebrafish have ciliogenesis defects that result in no OS development and rapid photoreceptor degeneration [185]. Fish with mutations in ift57 develop photoreceptor OSs, although they are shorter than normal, and photoreceptors degenerate soon after developing $[184,186]$. ift122 mutant zebrafish have normal photoreceptor development, but similarly undergo degeneration [187]. Zebrafish kif3a (kinesin family 3a) mutants fail to develop OSs and photoreceptors rapidly degenerate, and larvae have an extinguished ERG $[161,188,189]$. $n a p b b$ encodes a protein important for synaptic vesicle fusion [190] and napbb mutant photoreceptors undergo cell death almost immediately after specification [191,192]. No photoreceptor layer is detectable at early larval stages, with only a few photoreceptors observed at the ciliary margin [191,192]. IFT88, CLUAP1, IFT57, IFT122, KIF3A, and NAPB, 
mutations have not been associated with human photoreceptor disease, likely because of essential roles in development. IFT172 mutations have been associated with RP [193].

KIAA0586 mutations underlie a ciliopathy called Joubert syndrome, which presents with brain abnormalities and photoreceptor degeneration [194]. KIAA0586 is required for ciliogenesis. Developing photoreceptors in kiaa0586 mutant zebrafish have decreased OS development and degenerate rapidly after development [195]. Mutant larvae have significantly reduced ERG responses. TMEM216 is required for cilia assembly and TMEM216 mutations also cause Joubert syndrome in humans $[196,197]$. Knockout of tmem 216 resulted in decreased cone OS development, short OSs, disorganized OS discs, and degeneration [198]. GDF6 encodes a morphogen and its mutation causes LCA and juvenile RP in humans [199]. gdf6a mutant zebrafish larvae are functionally blind at $7 \mathrm{dpf}$ as determined by OMR, and have short, dysmorphic cone OSs and ISs, as well as overgrown, disorganized rod OSs and short ISs [199,200]. Photoreceptors do not undergo degeneration in these animals [199].

Table 5. Zebrafish mutant models of Leber congenital amaurosis-like photoreceptor disease.

\begin{tabular}{|c|c|c|}
\hline Gene & Photoreceptor Features & Reference \\
\hline cluap1 & No OS development, rapid photoreceptor degeneration. & [185] \\
\hline$g d f 6 a$ & Short, dysmorphic cones and expanded, disorganized rods at $7 \mathrm{dpf}$. & {$[199,200]$} \\
\hline ift57 & $\begin{array}{c}\text { Short OSs with normal disc stacking at } 4 \mathrm{dpf} \text {. Central retina photoreceptor } \\
\text { degeneration at } 5 \mathrm{dpf} .\end{array}$ & {$[184,186]$} \\
\hline ift 88 & No OS development, rapid photoreceptor degeneration. & [181-184] \\
\hline ift122 & $\begin{array}{c}\text { Normal photoreceptor OS development. Degeneration starting at } 7 \mathrm{dpf} \text {, severe } \\
\text { degeneration by } 10 \mathrm{dpf} \text {. }\end{array}$ & [187] \\
\hline ift172 & No OS development, rapid photoreceptor degeneration. & {$[181,182,184]$} \\
\hline kiaa0586 & $\begin{array}{c}\text { Fewer OSs observed at } 3 \mathrm{dpf} \text {, photoreceptor degeneration observed at } 4 \mathrm{dpf} \text {. } \\
\text { Decreased photoreceptor function detected at } 6 \mathrm{dpf} \text {. }\end{array}$ & [195] \\
\hline kif3a & $\begin{array}{l}\text { No OS development and rapid rod photoreceptor degeneration by } 5 \mathrm{dpf} \text {, } \\
\text { subsequent cone degeneration. Extinguished photoreceptor response at } 7 \mathrm{dpf} \text {. }\end{array}$ & {$[161,188,189]$} \\
\hline$n a p b b$ & $\begin{array}{l}\text { Immediate, severe photoreceptor degeneration; cell death observed at } 3 \mathrm{dpf} \text {, no } \\
\text { distinct photoreceptor layer at } 6 \mathrm{dpf} \text {, few photoreceptors in ciliary margin. }\end{array}$ & {$[191,192]$} \\
\hline tmem 216 & $\begin{array}{c}\text { Short cilia and disorganized OS discs by } 7 \mathrm{dpf} \text {, rapid degeneration. Few } \\
\text { photoreceptors remaining by } 14 \mathrm{dpf} \text {. }\end{array}$ & [198] \\
\hline
\end{tabular}

\subsubsection{Choroideremia}

Zebrafish rep1 knockout larvae have RPE that lacks uniformity with hypertrophic and de-pigmented regions [24] (Table 6). Additionally, the RPE has large vacuoles and accumulation of undigested OS fragments. The photoreceptor layer is disorganized with dysmorphic, functionally defective photoreceptors. The photoreceptor abnormalities appear to result from RPE dysfunction in these animals, as wild-type photoreceptors transplanted into mutant retina still become dysmorphic and degenerate, while rep1negative mutant photoreceptors transplanted into wild-type retinas are morphologically normal. rep1 mutant zebrafish do not survive to adulthood.

\subsubsection{Cone-Rod Dystrophy}

CC2D2A, AHI1, and ARL13B encode basal body or cilia-related proteins and their mutation causes forms of Joubert syndrome [201-203]. cc2d2a knockout zebrafish larvae have disorganized photoreceptor OSs and functional defects [204] (see Table 6 for zebrafish CORD mutants). Of interest, cilia assembly occurs normally in mutants, but trafficking of cilia components is impaired. Zebrafish larvae with ahi1 mutations have abnormal cone OSs but normal visual function, as assessed by OKR [205]. Cone OS morphology recovers by early adulthood, but cone morphology defects and degeneration are seen in five-month-old animals. At this age, rod photoreceptors have mislocalization of rhodopsin. Zebrafish arl13b mutant photoreceptors have short OSs [206]. Knockout arl13b larvae do not survive past $9 \mathrm{dpf}$, so transplantation experiments were performed to assess photoreceptor degeneration. The $a r l 13 b$ mutant photoreceptors had noticeable degeneration by $30 \mathrm{dpf}$. 
LCA5 is also a ciliary protein and mutations in the LCA5 gene cause LCA [207]. However, knockout of zebrafish lca5 results in a cone-rod dystrophy phenotype rather than LCA [208]. lca5 mutant larvae have decreased photoreceptor responses. Cone OS abnormalities are obvious at 1 month of age, while rod OS defects are observed at seven months. Mutations in PCARE, a regulator of cilium actin, cause RP [209]. Zebrafish larvae with mutations in pcare 1 have abnormal OS morphology, photoreceptor functional defects, and decreased OKR [210]. Adult pcare1 mutants have dysmorphic photoreceptor OSs and thin photoreceptor layers, indicative of degeneration. EYS mutations typically cause RP in human patients, although EYS mutations have also been associated with a cone-rod dystrophy [211-213]. The function of EYS is unknown, but a recent study found evidence that EYS localizes to the photoreceptor cilium and may be involved in cilium stability [214]. Zebrafish eys mutants have CORD, whereby cones degenerate in six-month-old animals and rod degeneration is observed at 8-14 months [215-217]. BBS2 is a basal body-associated protein necessary for proper ciliogenesis, and mutations in BBS2 lead to RP and a ciliopathy called Bardet-Biedl syndrome $[218,219]$. Larval bbs2 mutants have photoreceptor deficits observed by OKR and short, disorganized photoreceptor OSs [220]. In adulthood, photoreceptor degeneration is observed, along with regeneration of rods but not cones.

KCNJ13 encodes a channel protein found in the RPE and mutations in KCNJ13 lead to LCA [221]. Adult zebrafish with mutated kcnj13 have photoreceptor loss and RPE abnormalities [222]. Specifically, the RPE has increased phagosomes, enlarged mitochondria, and changes in melanosome localization, while cone photoreceptors have abnormal mitochondria and degenerate in aged animals. POMGNT1 is an enzyme that posttranslationally modifies other proteins, and POMGNT1 mutations cause RP [223]. Zebrafish with pomgnt1 have cone and rod degeneration at six months of age [224].

\subsubsection{Enhanced S-cone Syndrome}

A similar phenotype to human patients with enhanced S-cone syndrome is observed in $n r 2 e 3$ null zebrafish. Animals lack rod photoreceptors and undergo progressive cone degeneration [225] (Table 6). Interestingly, green and red cones degenerate while UV and blue cones persist. $n r l$ mutant larvae also do not develop rods, but intriguingly have increased UV cone photoreceptors [226]. Adult $n r l$ mutants unexpectedly have rods, but the rods have abnormal synapses. Whether these rods are functional is unknown.

Table 6. Zebrafish mutants of choroideremia, cone-rod dystrophy, and enhanced S-cone syndrome.

\begin{tabular}{|c|c|c|c|}
\hline Photoreceptor Disease & Gene & Photoreceptor + RPE Features & Reference \\
\hline Choroideremia & rep1 & $\begin{array}{l}\text { RPE irregularity and pigment loss. Disorganized photoreceptor layers, } \\
\text { dysmorphic photoreceptors, and significantly reduced photoreceptor responses at } \\
5 \mathrm{dpf} \text {. }\end{array}$ & [24] \\
\hline Cone-rod dystrophy & ahi1 & $\begin{array}{l}\text { Disorganized, short OSs, but normal visual function at } 5 \mathrm{dpf} \text {. Thin photoreceptor } \\
\text { nuclear layer, cone degeneration, and dysmorphic rods at } 5 \text { months. }\end{array}$ & [205] \\
\hline Cone-rod dystrophy & arl13b & Short OSs at $4 \mathrm{dpf}$. Cone degeneration observed at $30 \mathrm{dpf}$ in mosaic animals. & [206] \\
\hline Cone-rod dystrophy & $b b s 2$ & $\begin{array}{l}\text { Short, disorganized photoreceptor OSs and visual deficits at } 5 \mathrm{dpf} \text {. Photoreceptor } \\
\text { degeneration observed in adulthood. }\end{array}$ & [220] \\
\hline Cone-rod dystrophy & $c c 2 d 2 a$ & Dysmorphic photoreceptor OSs and functional defects at $5 \mathrm{dpf}$. & [204] \\
\hline Cone-rod dystrophy & eys & $\begin{array}{c}\text { Progressive photoreceptor loss; cone degeneration observed at } 6 \text { months, rod } \\
\text { degeneration observed at } 14 \text { months }\end{array}$ & {$[215-217]$} \\
\hline Cone-rod dystrophy & kcnj13 & $\begin{array}{c}\text { Increased phagosomes in the RPE at } 3 \text { months, enlarged RPE mitochondria at } 6 \\
\text { months, and abnormal melanosome localization under dark adaptation at } 12 \\
\text { months. Cone mitochondria abnormalities at } 6 \text { months and photoreceptor loss at } \\
12 \text { months. }\end{array}$ & [222] \\
\hline Cone-rod dystrophy & lca5 & $\begin{array}{l}\text { Photoreceptor functional defects at } 7 \mathrm{dpf} \text {. Cone OS defects at } 1 \text { month, rod OS } \\
\text { defects at } 7 \text { months, and progressive photoreceptor loss. }\end{array}$ & [208] \\
\hline Cone-rod dystrophy & pcare1 & $\begin{array}{l}\text { Dysmorphic OSs and dysfunctional photoreceptors at } 5 \mathrm{dpf} \text {. Abnormal OS } \\
\text { morphology and thinner photoreceptor layer at } 6 \text { months. }\end{array}$ & [210] \\
\hline $\begin{array}{l}\text { Cone-rod dystrophy } \\
\text { Enhanced S-cone syndrome }\end{array}$ & $\begin{array}{l}\text { pomgnt1 } \\
n r 2 e 3\end{array}$ & $\begin{array}{l}\text { Reduction in cones and rods at } 6 \text { months. } \\
\text { No rods. Green and red cone degeneration started at } 1 \text { month. }\end{array}$ & {$[224]$} \\
\hline Enhanced S-cone syndrome & $n r l$ & $\begin{array}{l}\text { Rods fail to develop and UV cones are over-abundant in larvae. Adult zebrafish } \\
\text { surprisingly have rods, but with synaptic defects. }\end{array}$ & [226] \\
\hline
\end{tabular}




\subsubsection{Cone Dystrophy}

PROM1 plays a critical role in outer segment disc morphogenesis and PROM1 mutations cause a variety of photoreceptor diseases, such as RP, CORD, and macular degeneration [227-229]. Zebrafish with prom $1 b$ mutations have a cone degeneration, starting with red and green cones and affecting blue and UV cones soon after [230] (Table 7; see for list of zebrafish mutant models of cone dystrophy). While rods do not appear to degenerate in prom $1 b$ mutants, they have overgrown OSs. CEP290 encodes a centrosomal protein and mutations are the most frequent cause of LCA [17]. Interestingly, cep290 mutant zebrafish have cone OS disorganization and degeneration in adulthood that is severe by 12 months, but normal rod OS morphology [231]. Why cep290 results in an adult onset, cone-specific phenotype in zebrafish is unknown, but may be due to alternative photoreceptor centrosomal proteins in zebrafish.

$P D E 6 C$ is an essential component of the cone phototransduction pathway and results in cone dystrophy when mutated [232]. pde6c-deficient zebrafish have rapid cone degeneration as well as dysmorphic, degenerate rods in larval stages [49,192]. In adulthood, mutants have severe cone degeneration but normal rod photoreceptors. AIPL1 is required for maintenance of photoreceptor phototransduction machinery and AIPL1 mutations can lead to LCA, RP, and CORD $[233,234]$. Zebrafish have two copies of this gene, aipl1a, which is expressed in rods and potentially UV cones, and aipl1b, which is expressed in all cones [235]. Zebrafish with mutations in aipl1b have progressive cone degeneration starting in larval stages, and by early adulthood have only a few single cones remaining [235]. Rod photoreceptors are unaffected.

Mutations in the retinal voltage-gated calcium channel subunit gene, CACNA2D4, lead to cone dystrophy [236]. Zebrafish have two paralogs of CACNA2D4: cacna2d4a and cacna2d4b [96]. Knocking out each paralog individually does not impact photoreceptor function in early development, but double knockout animals had reduced cone function [96]. ATP6V0E1 is a subunit of a proton pump and atp6v0e1 mutant zebrafish larvae have RPE pigment loss, outer retinal holes, visual defects determined by OKR, photoreceptor functional deficiencies assessed by ERG, and short OSs [237]. Rods were not assessed in these animals.

WRB is involved in recruitment of proteins to the endoplasmic reticulum, although its exact role in photoreceptors is unclear [238]. wrb mutant zebrafish larvae have holes in their photoreceptor layer, decreased or absent OMR, photoreceptor function deficits, and short cone ribbon synapses in early life $[239,240]$. Rods have not been investigated in these animals. Mutations in WRB have not been associated with human disease.

\subsubsection{Achromatopsia}

GNAT2 is an essential component of the cone phototransducation pathway and pathogenic variants in GNAT2 lead to achromatopsia [241]. gnat2 mutant zebrafish have cone dysfunction but the photoreceptors do not have overt morphological defects [242] (see Table 7 for mutant zebrafish achromatopsia models). Electrophysiological assessment suggested that gnat 2 mutant cones are $\sim 1000$ times less sensitive than wild-type cones. The rods are unaffected in these animals.

Pathogenic mutations in CACNA1F cause CORD and congenital stationary night blindness, a non-progressive condition characterized by rod dysfunction [243-245]. CACNA1F protein is a subunit of a voltage-gated calcium channel required at the photoreceptor synapse [246]. Zebrafish cacnalfa is cone-specific and mutant retinas have thin photoreceptor synaptic layers and decreased photoreceptor responses [97]. cacnalfa mutant cones do not develop synaptic ribbons. Similarly, zebrafish synj1 mutants have a thin photoreceptor synaptic layer and abnormal cone pedicles with unanchored synaptic ribbons [247-249]. The cone IS and OS appear normal [247-249]. Mutant zebrafish do not survive long enough to develop appreciable numbers of functional rods, but a transplantation study demonstrated that synj1 is required for cone synapse formation but not rod synapses [249]. A related phenotype is seen in per 2 knockout zebrafish; per 2 mutant larvae have an abnormal 
VMR, untethered ribbon synapses, and decreases in cone opsin expression which may indicate cone degeneration [250]. Animals have not been aged for further investigation of cone and rod viability.

\subsubsection{Age-Related Macular Degeneration}

AMD models are challenging to generate as AMD is a multifactorial condition. However, there are zebrafish models with features of AMD. Recently, rp1l1 mutant zebrafish were reported to have progressive photoreceptor dysfunction and subretinal drusenoid deposits [170] (Table 4). This is the first report of subretinal drusenoid deposits in zebrafish, and may provide insight into how drusenoid deposits develop and impact photoreceptor function. In addition, models of neovascularization are relevant to wet AMD. Zebrafish larvae with mutations in $v h l$ present with retinal neovascularization, leaky vessels, and develop oedema and retinal detachment [251] (Table 7).

Table 7. Zebrafish mutant models of cone dystrophy, achromatopsia, and retinal neovascularization.

\begin{tabular}{|c|c|c|c|}
\hline Photoreceptor Disease & Gene & Photoreceptor, RPE, or Vascular Features & Reference \\
\hline Achromatopsia & cacnalfa & $\begin{array}{l}\text { Thin photoreceptor synaptic layer. Photoreceptor } \\
\text { functional defects at 5-6 dpf. Cone synapses do not } \\
\text { develop synaptic ribbons. }\end{array}$ & [97] \\
\hline Achromatopsia & gnat2 & $\begin{array}{c}\text { Cone functional defects under dim to moderate light } \\
\text { intensities. }\end{array}$ & [242] \\
\hline Achromatopsia & per2 & $\begin{array}{c}\text { Visually-mediated behaviour deficiencies at } 5-6 \mathrm{dpf} \text {. } \\
\text { Unanchored cone ribbon synapses and decreased cone } \\
\text { opsin expression. }\end{array}$ & [250] \\
\hline Achromatopsia & synj1 & $\begin{array}{l}\text { Thin photoreceptor synaptic layer and abnormal, } \\
\text { unanchored cone ribbon synapses at } 6 \mathrm{dpf} \text {. }\end{array}$ & [247-249] \\
\hline Cone dystrophy & aipl1 & $\begin{array}{l}\text { Thin photoreceptor layer and OS defects at } 7 \mathrm{dpf} \text {. Severe } \\
\text { cone degeneration by } 3 \text { months. }\end{array}$ & [235] \\
\hline Cone dystrophy & $\operatorname{atp} 6 v 0 e 1$ & $\begin{array}{l}\text { Hypopigmented RPE, reduced or absent visual response, } \\
\text { decreased photoreceptor function, short OSs, and outer } \\
\text { retinal holes at } 5 \mathrm{dpf} \text {. }\end{array}$ & [237] \\
\hline Cone dystrophy & cacna $2 d 4 a+$ cacna $2 d 4 b$ & Mild cone dysfunction at $20 \mathrm{dpf}$ & [96] \\
\hline & сер 290 & $\begin{array}{l}\text { Cone OS abnormalities and degeneration at } 3 \text { months, } \\
\text { severe degeneration at } 12 \text { months. Normal rods. }\end{array}$ & [231] \\
\hline Cone dystrophy & pde6c & $\begin{array}{c}\text { Cone degeneration at } 4 \mathrm{dpf} \text { and rod subsequently become } \\
\text { dysmorphic and degenerate in the larval retina. At } 3 \\
\text { months, cones are degenerate and largely missing, rods are } \\
\text { normal. }\end{array}$ & {$[49,192]$} \\
\hline Cone dystrophy & prom $1 b$ & $\begin{array}{c}\text { Progressive cone degeneration. Reduced red and green } \\
\text { cones at } 7 \text { dpf; reduced UV and blue cones at } 1 \text { month. } \\
\text { Overgrown rod OSs. }\end{array}$ & [230] \\
\hline Cone dystrophy & $w r b$ & $\begin{array}{l}\text { Holes in the photoreceptor layer at } 4 \mathrm{dpf} \text {. Vision defects at } \\
5 \mathrm{dpf} \text {, photoreceptor function defects at } 4-5 \mathrm{dpf} \text {. Small cone } \\
\text { ribbon synapses }\end{array}$ & {$[239,240]$} \\
\hline $\begin{array}{c}\text { Retinal } \\
\text { neovascularization }\end{array}$ & vhl & $\begin{array}{l}\text { Retinal neovascularization, leaky blood vessels, retinal } \\
\text { oedema, and retinal detachment at } 7-8 \mathrm{dpf} \text {. }\end{array}$ & [251] \\
\hline
\end{tabular}

\subsection{Relevance to Human Disease}

In order to understand and prevent photoreceptor disease, a keen knowledge of how photoreceptor development, function, and maintenance is required. Zebrafish have provided additional information about factors involved in these aspects, as lines with mutations in genes not associated with human photoreceptor disease, potentially due to lethality, have impaired or degenerate photoreceptors. Additionally, the cellular abnormalities and cause of photoreceptor death can be investigated in these models. For example, genetically mosaic zebrafish generated by transplantation experiments with zebrafish rep 1 mutants determined that rep1 loss in photoreceptors does not lead to photoreceptor degeneration, but rather that rep1 is required for normal RPE function, and photoreceptors die due to RPE dysfunction in rep1 mutant retina [24]. 
Models of cone disease are desperately needed, as preservation of the high-acuity central vision is a priority for patients and physicians. Nocturnal rodent models are not an ideal system for these conditions, as they have a low density of cones and their cones have some properties that are distinct from human cones, such as expression of multiple opsins in a single cell. Indeed, some mouse models of cone diseases do not have the expected cone degeneration phenotype [252]. The zebrafish retina allows for the investigation of cone diseases, and the numerous genetic models provide the opportunity to determine disease mechanisms based on the mutated gene.

In addition, the cone-rich zebrafish retina enables the assessment of how rod loss impacts cone photoreceptors. Cone persistence post rod death in adult zebrafish RP models permits determination of how cones respond to rod loss and the factors that influence their health when neighbouring photoreceptors degenerate. Additionally, while cones appear viable post rod loss in RP zebrafish models, $p d e 6 c$ mutant larvae have rod degeneration post cone loss despite the cone-specific genetic lesion $[49,192]$. This suggests that the minority photoreceptor type is inherently susceptible to death, as the cone-dominant larval zebrafish retina undergoes rod degeneration post cone loss while the rod-dominant human retina experiences cone degeneration post rod loss. The pde6c mutants can therefore be utilized to determine why the minority photoreceptor type is sensitive to degeneration and provide avenues to preserve the cells, which is relevant to efforts aimed at protecting cones in late-stage RP.

Interestingly, several zebrafish models of photoreceptor disease have red and green cone degeneration prior to UV and blue cone degeneration [166,180,225,230,235]. Whether this is due to structural distinctions between double and single cones, or whether there are specific features of longer-wavelength sensitive cones that make them more susceptible to cell death than short wavelength cones, is unknown. Further assessment is required and may inform macular degeneration pathologies. The central macula is comprised of primarily red and green cones, and understanding what makes these cones vulnerable to disease is important for preventing AMD.

Drusen and subretinal drusenoid deposits are characteristic features of AMD but how they develop and their effect on photoreceptor health is unknown. Animal models of drusen and drusenoid deposits are difficult to develop and there a few photoreceptor disease models that acquire them. Subretinal drusenoid deposits in particular are poorly investigated, as they are relatively newly characterized. A zebrafish model of photoreceptor disease with accompanying subretinal drusenoid deposits provides the opportunity to investigate how these lipid accumulations develop in vivo [170].

\section{Contribution to Therapeutics}

Zebrafish provide a model to test therapeutic strategies and pharmaceuticals. Numerous disease models combined with the small size of zebrafish larvae and visual tools, such as VMR, OMR, and OKR, allow for screening of compounds. Below, the contributions from zebrafish models are outlined.

\subsection{Pharmaceuticals}

\subsubsection{Anti-Angiogenic Compounds}

Zebrafish models of retinal neovascularization, such as the hypoxia-induced model and vhl mutants, provide the opportunity to screen for anti-angiogenic compounds that could be employed in patients with wet AMD. Indeed, Van Rooijen and colleagues found that treating vhl mutants with vascular endothelial growth factor receptor (VEGFR) tyrosine kinase inhibitors typically used in cancer treatment successfully blocked pathogenic angiogenesis [251], which could be further tested in mammalian models of retinal neovascularization.

\subsubsection{Histone Deacetylase Inhibition}

Cellular stress markers can activate cell death pathways, resulting in apoptosis, or trigger elimination by immune cells. This can result in loss of cells that were stressed, but 
otherwise functional, and has been observed in the retina [253]. Overactivation of histone deacetylases (HDACs) has been detected in models of photoreceptor degeneration [254]. Indeed, HDAC inhibitors have been effective for treating neuronal pathologies in vitro and in animal models of CNS disease, including photoreceptor degeneration models [255-257]. However, it is important to note that there are also HDACs that inhibit photoreceptor death after light injury [258]; it is therefore important to target specific HDACs.

HDAC6 inhibition has been reported to prevent neurodegeneration in peripheral neuropathy models [259]. In the atp6v0e mutant zebrafish model of cone photoreceptor disease, HDAC6 inhibitors successfully restored OKR, decreased the number of apoptotic cells in the photoreceptor layer, and increased OS persistence $[237,260,261]$. Similar results are observed in a mouse model of photoreceptor disease [260,261], further supporting HDAC6 as a potential therapeutic target for treating photoreceptor degenerations.

\subsubsection{Novel Compound Screening}

Zebrafish models of photoreceptor disease provide a platform for discovery of novel neuroprotective drugs. Zebrafish have been employed for numerous large drug screens, such as screens to identify compounds that impact neuronal activity [262,263]. Zebrafish can therefore be utilized to identify novel compounds in large-scale screens. Through behavioural screens and histological approaches, several compounds have been identified as protective against photoreceptor dysfunction and degeneration in zebrafish.

Ganzen and colleagues utilized $\operatorname{Tg}(r h o: h s a R H O-Q 344 X)$ and transgenics with NTRablatable rods to screen a library of potential drugs for potential RP treatment [264] (bioRxiv preprint). VMR assessment identified carvedilol as beneficial, and carvedilol-treated $\operatorname{Tg}($ rho:hsaRHO-Q344X) larvae had increased rod survival compared to control animals. As $\mathrm{RP}$ is the most common inherited photoreceptor disease, a pharmacological treatment may have applicability to many patients experiencing progression vision loss.

Cone degeneration in pde $6 c$ mutant zebrafish larvae occurs through nectroptosis, while the subsequent rod degeneration is apoptosis-mediated [265]. Blocking necroptosis factors using necrostatin-1s or necrosulfonamide at $10 \mathrm{hpf}$ until $7 \mathrm{dpf}$ results in a reduction in cone death [265]. However, whether vision is preserved due to necrostatin-1s or necrosulfonamide treatment is unknown. Further investigation is required, but pharmacological repression of necroptosis has applicability to many different photoreceptor diseases that involve necroptosis pathways.

Studies using zebrafish models of photoreceptor disease have also identified schisandrin $B$ and gypenoside, plant-derived compounds with antioxidant and anti-inflammatory properties, as potential neuroprotective compounds [266-271]. These examples highlight the benefits of utilizing zebrafish models of photoreceptor disease to screen novel therapeutics and specific drugs.

\subsubsection{Oculotoxicity}

Many drugs have retinal toxicity, meaning that prolonged exposure can result in retinal damage and vision loss. Zebrafish have provided a relatively high-throughput tool to assess retinal toxicity of pharmaceuticals. Deeti and colleagues used zebrafish larvae to develop a methodology for assessing the impact of pharmaceuticals on the zebrafish visual system [272]. Thereby, $3 \mathrm{dpf}$, zebrafish larvae were treated with compounds for 2 days in 48-well plates, and then assessed for visual impairment using VMR and OKR. $5 / 6$ known oculotoxic drugs reduced the visual responses of zebrafish. However, all of the oculotoxic drugs resulted in a reduction in zebrafish touch response, suggesting defects in other sensory neurons. Therefore, zebrafish provide a viable tool for screening drugs for retinal toxicity.

\subsection{Antisense Oligonucleotide Therapy}

Antisense oligonucleotide therapy can block aberrant splicing in genes with mutations in splice donor or acceptor sites. A frequent Usher syndrome-causing USH2A mutation 
results in incorporation of a psuedoexon and truncation of the USH2A protein [273]. Morpholino treatment successfully prevented aberrant splicing in mosaic zebrafish with ush $2 a$ containing a CRISPR/Cas-introduced region of human mutant USH2A [274]. In addition, this group recently investigated morpholino-induced skipping of a mutated exon in ush2a mutant zebrafish [275] (preprint); specifically, they skipped mutant exon 13, which is commonly mutated in Usher syndrome $[178,276]$. Exon skipping was successful and partially restored protein expression [275] (preprint). This therapeutic approach of using antisense oligonucleotides to partially restore $U S H 2 A$ function by skipping the problematic exon 13 is currently in clinical trial (ID: NCT03780257).

\subsection{Photoreceptor Regenerative Pathways}

Zebrafish can regenerate lost retinal neurons, including photoreceptors [277]. Investigating the zebrafish regenerative response provides information on activation of endogenous retinal stem cells as well as factors that promote photoreceptor differentiation and integration of newly generated cells, which is invaluable for effective development and deployment of stem cell therapies.

Zebrafish have two distinct stem cell pools: the ciliary marginal zone (CMZ) and Müller glia.

\subsubsection{Ciliary Marginal Zone}

The CMZ is a pool of retinal stem cells located at the peripheral edges of the retina. In many species, this pool becomes inactive once the retina has matured. However, in many vertebrates, such as zebrafish and other species that undergo indeterminate growth, the $\mathrm{CMZ}$ self-renews and constantly adds new retinal neurons at the edges of the retina. The CMZ contains both retinal stem cells, which can divide indeterminately, and retinal progenitor cells, which can only divide a certain number of times and lose contact with the CMZ as differentiation occurs [104,277-279]. Retinal stem cells sit in the edges of the CMZ, and typically undergo asymmetrical division to produce a retinal stem cell and a retina progenitor cell [104,277-279].

Mammals have a CMZ-like region that gives rise to some retinal neurons during development [280], although whether it has the capacity to produce photoreceptors is unclear. In the mature retina, these retinal margin cells seem to lose neurogenesis capacity or become quiescent. However, there are cells with stem cell-like properties in the mammalian/human peripheral retinal margin net to the pars plana; specifically, Müller glia and ciliary epithelium cells that express neural progenitor markers [281-283]. Whether these cell populations could be stimulated to enter a stem cell-like fate in the damaged retina requires further investigation.

\subsubsection{Müller Glia}

Müller glia are support cells that play many essential roles in the retina, including ion regulation, neurotransmitter uptake and degradation, cellular debris removal, and neuronal insulation. In zebrafish and other teleost fishes, Müller glia also act as endogenous stem cells by undergoing de-differentiation, proliferation, and specification to produce many different retinal neuron types, including photoreceptors [281-283]. Zebrafish Müller glia division is asymmetrical, allowing for replenishment of lost retinal neurons while maintaining the stem cell pool [99,104,107,279,284-287]. As mentioned above, there is a threshold of damage that must be met to trigger the Müller glial regenerative response, which has been observed in NTR ablation studies [60,125-129]. Interestingly, some mutant zebrafish have cone degeneration but Müller glia do not undergo proliferation to regenerate the lost photoreceptors $[220,231]$. Further investigation into one of these lines, the bbs2 mutants, found that the endogenous Müller glia do have the capacity to regenerate retinal neurons in bbs2 mutant retina, as evident by light ablation experiments [220]. Why photoreceptor degeneration triggers a regenerative response in some mutant models but 
not others is unclear, but may be related to the speed of degeneration or an inflammatory requirement for Müller glia activation.

Zebrafish Müller glial behaviour must be carefully controlled in order to prevent aberrant proliferation and production of unneeded neurons. In the uninjured retina, the reprograming pathways of Müller glia are inhibited [288]. After retinal injury, Müller glia respond to factors released by damaged cells—including TNF $\alpha$ [289]—and undergo reprogramming, followed by proliferation and neurogenesis. Studying the regenerative pathways in zebrafish has provided insight into stem cell and fate-determining factors that can be utilized to generate photoreceptor precursor cells for transplantation.

As Müller glia are interspersed within the human retina, how the stem cell behaviour of Müller glia is activated and whether mature mammalian Müller glia can be re-programmed to a stem cell fate to treat retinal degenerations is an area of active interest. Human Müller glia respond to damage and have stem cell-like characteristics, but do not naturally undergo neurogenesis in vivo [281,290]. Müller glia proliferation is rare in the mammalian retina, usually associated with scar formation [291]. In culture, human Müller glia treated with growth and differentiation factors can take on stem cell characteristics and differentiate into rod photoreceptors [281,290,292]. Rod photoreceptors derived from human Müller glia cultures have successfully been introduced into a rat model of RP. These cells are able to migrate into the ONL and restore some visual function [293]. Further investigations into Müller glial response to photoreceptor loss, photoreceptor cell differentiation, and integration will be essential for application of stem cell therapies in human disease, and zebrafish provide this unique avenue. For in-depth reviews of photoreceptor regeneration in zebrafish and how these mechanisms relate to mammalian systems, please see $[145,294-298]$.

\section{Conclusions}

Zebrafish provide the unique opportunity to model photoreceptor disease in a conerich retina, similar to the human macula. There are inducible, transgenic, and mutant zebrafish models that encompass the entire spectrum of photoreceptor disease. These models can be further utilized to elucidate disease mechanism, test therapeutics, and screen novel compounds. In addition, the robust regenerative capacity of the zebrafish retina allows for the characterization of endogenous stem cells.

Funding: This work was funded by the Canadian Institutes of Health Research through a Rare Disease Models and Mechanisms grant to W.T.A. and I.M.M. and a Rare Disease Foundation microgrant to I.M.M. and N.C.L.N. N.C.L.N. was supported by a Doctoral Recruitment Scholarship from University of Alberta, Alberta Innovates Doctoral Graduate Student Scholarship, Frederick Banting and Charles Best Canada Graduate Scholarship from the Canadian Institutes of Health Research, a President's Doctoral Prize of Distinction from University of Alberta, and a Queen Elizabeth II PhD Scholarship from the Government of Alberta.

Institutional Review Board Statement: Not applicable.

Informed Consent Statement: Not applicable.

Data Availability Statement: Data sharing not applicable.

Conflicts of Interest: The authors declare no conflict of interest.

\section{References}

1. Daiger, S.P.; Rossiter, B.J.F.; Greenberg, J.; Christoffels, A.; Hide, W. RetNet. Available online: https://sph.uth.edu/RetNet/ (accessed on 10 December 2020).

2. Nathans, J.; Thomas, D.; Hogness, D.S. Molecular genetics of human color vision: The genes encoding blue, green, and red pigments. Science 1985, 232, 193-202. [CrossRef] [PubMed]

3. Bowmaker, J.K.; Dartnall, H.J.A. Visual pigments of rods and cones in a human retina. J. Physiol. 1980, 298, 501-511. [CrossRef] [PubMed]

4. Hofer, H.; Carroll, J.; Neitz, J.; Neitz, M.; Williams, D.R. Organization of the human trichromatic cone mosaic. J. Neurosci. 2005, 25, 9669-9679. [CrossRef] [PubMed] 
5. Curcio, C.A.; Sloan, K.R.; Packer, O.; Hendrickson, A.E.; Kalina, R.E. Distribution of cones in human and monkey retina: Individual variability and radial asymmetry. Science 1987, 236, 579-582. [CrossRef] [PubMed]

6. Schultze, M. Zur Anatomie and Physiologie der Retina. Ach Mikr Anat. 1866, 2, 175-286. [CrossRef]

7. Strauss, O. The retinal pigment epithelium in visual function. Physiol. Rev. 2005, 85, 845-881. [CrossRef]

8. Cayouette, M.; Smith, S.B.; Becerra, S.P.; Gravel, C. Pigment epithelium-derived factor delays the death of photoreceptors in mouse models of inherited retinal degenerations. Neurobiol. Dis. 1999, 6, 523-532. [CrossRef]

9. Becerra, S.P.; Fariss, R.N.; Wu, Y.Q.; Montuenga, L.M.; Wong, P.; Pfeffer, B.A. Pigment epithelium-derived factor in the monkey retinal pigment epithelium and interphotoreceptor matrix: Apical secretion and distribution. Exp. Eye Res. 2004, 78, 223-234. [CrossRef]

10. Ogata, N.; Wang, L.; Jo, N.; Tombran-Tink, J.; Takahashi, K.; Mrazek, D.; Matsumura, M. Pigment epithelium derived factor as a neuroprotective agent against ischemic retinal injury. Curr. Eye Res. 2001, 22, 245-252. [CrossRef]

11. Reiter, J.F.; Leroux, M.R. Genes and molecular pathways underpinning ciliopathies. Nat. Rev. Mol. Cell Biol. 2017, 18, 533-547. [CrossRef]

12. National Eye Institute (National Institutes of Health) AMD Data and Statistics. Available online: https://www.nei.nih.gov/ learn-about-eye-health/resources-for-health-educators/eye-health-data-and-statistics/age-related-macular-degenerationamd-data-and-statistics (accessed on 10 December 2020).

13. Hamel, C. Retinitis pigmentosa. Orphanetj. Rare Dis. 2006, 1, 40. [CrossRef]

14. Hanany, M.; Rivolta, C.; Sharon, D. Worldwide carrier frequency and genetic prevalence of autosomal recessive inherited retinal diseases. Proc. Natl. Acad. Sci. USA 2020, 117, 2710-2716. [CrossRef] [PubMed]

15. Santer, R.; Schneppenheim, R.; Dombrowski, A.; Gotze, H.; Steinmann, B.; Schaub, J. Mutations in RPE65 cause Leber's congenital amaurosis. Nat. Genet. 1997, 15, 57-61.

16. Perrault, I.; Rozet, J.M.; Calvas, P.; Gerber, S.; Camuzat, A.; Dollfus, H.; Châtelin, S.; Souied, E.; Ghazi, I.; Leowski, C.; et al. Retinal-specific guanylate cyclase gene mutations in Leber's congenital amaurosis. Nat. Genet. 1996, 14, 461-464. [CrossRef] [PubMed]

17. den Hollander, A.I.; Koenekoop, R.K.; Yzer, S.; Lopez, I.; Arends, M.L.; Voesenek, K.E.; Zonneveld, M.N.; Strom, T.M.; Meitinger, T.; Brunner, H.G.; et al. Mutations in the CEP290 (NPHP6) gene are a frequent cause of Leber congenital amaurosis. Am. J. Hum. Genet. 2006, 79, 556-561. [CrossRef] [PubMed]

18. Chacon-Camacho, O.F. Review and update on the molecular basis of Leber congenital amaurosis. Worldj. Clin. Cases 2015, 3, 112. [CrossRef]

19. Xue, L.; Gollapalli, D.R.; Maiti, P.; Jahng, W.J.; Rando, R.R. A palmitoylation switch mechanism in the regulation of the visual cycle. Cell 2004, 117, 761-771. [CrossRef]

20. Wimberg, H.; Lev, D.; Yosovich, K.; Namburi, P.; Banin, E.; Sharon, D.; Koch, K.W. Photoreceptor guanylate cyclase (GUCY2D) mutations cause retinal dystrophies by severe malfunction of $\mathrm{Ca}^{2+}$-dependent cyclic GMP synthesis. Front. Mol. Neurosci. 2018, 11, 1-12. [CrossRef]

21. Azadi, S.; Molday, L.L.; Molday, R.S. RD3, the protein associated with Leber congenital amaurosis type 12, is required for guanylate cyclase trafficking in photoreceptor cells. Proc. Natl. Acad. Sci. USA 2010, 107, 21158-21163. [CrossRef]

22. Chang, B.; Khanna, H.; Hawes, N.; Jimeno, D.; He, S.; Lillo, C.; Parapuram, S.K.; Cheng, H.; Scott, A.; Hurd, R.E.; et al. In-frame deletion in a novel centrosomal/ciliary protein CEP290/NPHP6 perturbs its interaction with RPGR and results in early-onset retinal degeneration in the rd16 mouse. Hum. Mol. Genet. 2006, 15, 1847-1857. [CrossRef]

23. Seabra, M.C.; Brown, M.S.; Goldstein, J.L. Retinal degeneration in choroideremia: Deficiency of Rab geranylgeranyl transferase. Science 1993, 259, 377-381. [CrossRef]

24. Krock, B.L.; Bilotta, J.; Perkins, B.D. Noncell-autonomous photoreceptor degeneration in a zebrafish model of choroideremia. Proc. Natl. Acad. Sci. USA 2007, 104, 4600-4605. [CrossRef]

25. Wavre-Shapton, S.T.; Tolmachova, T.; da Silva, M.L.; Futter, C.E.; Seabra, M.C. Conditional ablation of the choroideremia gene causes age-related changes in mouse retinal pigment epithelium. PLoS ONE 2013, 8, 1-11. [CrossRef]

26. Haider, N.B.; Jacobson, S.G.; Cideciyan, A.V.; Swiderski, R.; Streb, L.M.; Searby, C.; Beck, G.; Hockey, R.; Hanna, D.B.; Gorman, S.; et al. Mutation of a nuclear receptor gene, NR2E3, causes enhanced S cone syndrome, a disorder of retinal cell fate. Nat. Genet. 2000, 24, 127-131. [CrossRef]

27. Nishiguchi, K.M.; Friedman, J.S.; Sandberg, M.A.; Swaroop, A.; Berson, E.L.; Dryja, T.P. Recessive NRL mutations in patients with clumped pigmentary retinal degeneration and relative preservation of blue cone function. Proc. Natl. Acad. Sci. USA 2004, 101, 17819-17824. [CrossRef]

28. Newman, H.; Blumen, S.C.; Braverman, I.; Hanna, R.; Tiosano, B.; Perlman, I.; Ben-Yosef, T. Homozygosity for a recessive loss-of-function mutation of the NRL gene is associated with a variant of enhanced S-cone syndrome. Investig. Ophthalmol. Vis. Sci. 2016, 57, 5361-5371. [CrossRef]

29. Littink, K.W.; Stappers, P.T.Y.; Riemslag, F.C.C.; Talsma, H.E.; van Genderen, M.M.; Cremers, F.P.M.; Collin, R.W.J.; van den Born, L.I. Autosomal recessive NRL mutations in patients with enhanced S-cone syndrome. Genes 2018, 9, 68. [CrossRef]

30. Sisk, R.A.; Hufnagel, R.B.; Laham, A.; Wohler, E.S.; Sobreira, N.; Ahmed, Z.M. Peripheral cone dystrophy: Expanded clinical spectrum, multimodal and ultrawide-field imaging, and genomic analysis. J. Ophthalmol. 2018, 2018. [CrossRef] 
31. Remmer, M.H.; Rastogi, N.; Ranka, M.P.; Ceisler, E.J. Achromatopsia: A review. Curr. Opin. Ophthalmol. 2015, 26, 333-340. [CrossRef]

32. Viets, K.; Eldred, K.C.; Johnston, R.J. Mechanisms of photoreceptor patterning in vertebrates and invertebrates. Trends Genet. 2016, 32, 638-659. [CrossRef]

33. Kostic, C.; Arsenijevic, Y. Animal modelling for inherited central vision loss. J. Pathol. 2016, 238, 300-310. [CrossRef]

34. Schmitt, E.A.; Hyatt, G.A.; Dowling, J.E. Erratum: Temporal and spatial patterns of opsin gene expression in the zebrafish (Danio rerio): Corrections with additions. Vis. Neurosci. 1999, 16, 601-605. [CrossRef]

35. Robinson, J.; Schmitt, E.A.; Dowling, J.E. Temporal and spatial patterns of opsin gene expression in zebrafish (Danio rerio). Vis. Neurosci. 1995, 12, 895-906. [CrossRef]

36. Neuhauss, S.C.F. Behavioral genetic approaches to visual system development and function in zebrafish. J. Neurobiol. 2003, 54, 148-160. [CrossRef]

37. Allison, W.T.; Barthel, L.K.; Skebo, K.M.; Takechi, M.; Kawamura, S.; Raymond, P.A. Ontogeny of cone photoreceptor mosaics in zebrafish. J. Comp. Neurol. 2010, 518, 4182-4195. [CrossRef]

38. Yoshimatsu, T.; Schröder, C.; Nevala, N.E.; Berens, P.; Baden, T. Fovea-like photoreceptor specializations underlie single UV cone driven prey-capture behavior in zebrafish. Neuron 2020, 107, 320-337.e6. [CrossRef]

39. Fadool, J.M. Development of a rod photoreceptor mosaic revealed in transgenic zebrafish. Dev. Biol. 2003, 258, 277-290. [CrossRef]

40. Noel, N.C.L.; Allison, W.T. Connectivity of cone photoreceptor telodendria in the zebrafish retina. J. Comp. Neurol. 2018, 526, 609-625. [CrossRef]

41. Morrow, J.M.; Lazic, S.; Fox, M.D.; Kuo, C.; Schott, R.K.; De Gutierrez, E.A.; Santini, F.; Tropepe, V.; Chang, B.S.W. A second visual rhodopsin gene, rh1-2, is expressed in zebrafish photoreceptors and found in other ray-finned fishes. J. Exp. Biol. 2017, 220, 294-303. [CrossRef]

42. Takechi, M.; Kawamura, S. Temporal and spatial changes in the expression pattern of multiple red and green subtype opsin genes during zebrafish development. J. Exp. Biol. 2005, 208, 1337-1345. [CrossRef]

43. Morrow, J.M.; Lazic, S.; Chang, B.S.W. A novel rhodopsin-like gene expressed in zebrafish retina. Vis. Neurosci. 2011, 28, 325-335. [CrossRef] [PubMed]

44. Ruzicka, L.; Howe, D.G.; Ramachandran, S.; Toro, S.; Van Slyke, C.E.; Bradford, Y.M.; Eagle, A.; Fashena, D.; Frazer, K.; Kalita, P.; et al. The Zebrafish Information Network: New support for non-coding genes, richer Gene Ontology annotations and the Alliance of Genome Resources. Nucleic Acids Res. 2019, 47, D867-D873. [CrossRef]

45. Kennedy, B.N.; Alvarez, Y.; Brockerhoff, S.E.; Stearns, G.W.; Sapetto-Rebow, B.; Taylor, M.R.; Hurley, J.B. Identification of a zebrafish cone photoreceptor-specific promoter and genetic rescue of achromatopsia in the nof mutant. Investig. Ophthalmol. Vis. Sci. 2007, 48, 522-529. [CrossRef]

46. Hamaoka, T.; Takechi, M.; Chinen, A.; Nishiwaki, Y.; Kawamura, S. Visualization of rod photoreceptor development using GFP-transgenic zebrafish. Genesis 2002, 34, 215-220. [CrossRef]

47. Takechi, M.; Hamaoka, T.; Kawamura, S. Fluorescence visualization of ultraviolet-sensitive cone photoreceptor development in living zebrafish. Febs Lett. 2003, 553, 90-94. [CrossRef]

48. DuVal, M.G.; Chung, H.; Lehmann, O.J.; Allison, W.T. Longitudinal fluorescent observation of retinal degeneration and regeneration in zebrafish using fundus lens imaging. Mol. Vis. 2013, 19, 1082-1095.

49. Stearns, G.; Evangelista, M.; Fadool, J.M.; Brockerhoff, S.E. A mutation in the cone-specific pde6 gene causes rapid cone photoreceptor degeneration in zebrafish. J. Neurosci. 2007, 27, 13866-13874. [CrossRef]

50. DuVal, M.G.; Oel, A.P.; Allison, W.T. gdf6a is required for cone photoreceptor subtype differentiation and for the actions of tbx $2 \mathrm{~b}$ in determining rod versus cone photoreceptor fate. PLoS ONE 2014, 9, e92991. [CrossRef]

51. Yin, J.; Brocher, J.; Linder, B.; Hirmer, A.; Sundaramurthi, H.; Fischer, U.; Winkler, C. The 1D4 antibody labels outer segments of long double cone but not rod photoreceptors in zebrafish. Investig. Ophthalmol. Vis. Sci. 2012, 53, 4943-4951. [CrossRef]

52. Larison, K.D.; Bremiller, R. Early onset of phenotype and cell patterning in the embryonic zebrafish retina. Development 1990, 109, $567-576$

53. Ile, K.E.; Kassen, S.; Cao, C.; Vihtehlic, T.; Shah, S.D.; Mousley, C.J.; Alb, J.G., Jr.; Huijbregts, R.P.; Stearns, G.W.; Brockerhoff, S.E.; et al. Zebrafish class 1 phosphatidylinositol transfer proteins: PITPbeta and double cone cell outer segment integrity in retina. Traffic 2010, 11, 1151-1167. [CrossRef]

54. Schmitt, E.A.; Dowling, J.E. Comparison of topographical patterns of ganglion and photoreceptor cell differentiation in the retina of the zebrafish, Danio rerio. J. Comp. Neurol. 1996, 371, 222-234. [CrossRef]

55. Brockerhoff, S.E.; Hurley, J.B.; Janssen-Bienhold, U.; Neuhauss, S.C.F.; Driever, W.; Dowling, J.E. A behavioral screen for isolating zebrafish mutants with visual system defects. Proc. Natl. Acad. Sci. USA 1995, 92, 10545-10549. [CrossRef]

56. Brockerhoff, S.E. Measuring the optokinetic response of zebrafish larvae. Nat. Protoc. 2006, 1, 2448-2451. [CrossRef]

57. Easter, S.S.; Nicola, G.N. The development of eye movements in the zebrafish (Danio rerio). Dev. Psychobiol. 1997, 31, 267-276. [CrossRef]

58. Orger, M.B.; Gahtan, E.; Muto, A.; Page-McCaw, P.; Smear, M.C.; Baier, H. Behavioral screening assays in zebrafish. Methods Cell Biol. 2004, 77, 53-68. [CrossRef]

59. Orger, M.B.; Smear, M.C.; Anstis, S.M.; Baier, H. Perception of Fourier and non-Fourier motion by larval zebrafish. Nat. Neurosci. 2000, 3, 1128-1133. [CrossRef] 
60. Hagerman, G.F.; Noel, N.C.L.; Cao, S.; DuVal, M.G.; Oel, A.P.; Allison, W.T. Rapid recovery of visual function associated with blue cone ablation in zebrafish. PLoS ONE 2016, 11. [CrossRef]

61. Emran, F.; Rihel, J.; Dowling, J.E. A behavioral assay to measure responsiveness of zebrafish to changes in light intensities. J. Vis. Exp. 2008, 20, 1-6. [CrossRef]

62. Fernández, E.J.; Hermann, B.; Považay, B.; Unterhuber, A.; Sattmann, H.; Hofer, B.; Ahnelt, P.K.; Drexler, W. Ultrahigh resolution optical coherence tomography and pancorrection for cellular imaging of the living human retina. Opt. Express 2008, $16,11083$. [CrossRef]

63. Huckenpahler, A.L.; Wilk, M.A.; Cooper, R.F.; Moehring, F.; Link, B.A.; Carroll, J.; Collery, R.F. Imaging the adult zebrafish cone mosaic using optical coherence tomography. Vis. Neurosci. 2016, 33, E011. [CrossRef]

64. Collery, R.F.; Veth, K.N.; Dubis, A.M.; Carroll, J.; Link, B.A. Rapid, accurate, and non-invasive measurement of zebrafish axial length and other eye dimensions using SD-OCT allows longitudinal analysis of myopia and emmetropization. PLoS ONE 2014, 9. [CrossRef]

65. Nadolski, N.J.; Wong, C.X.L.; Hocking, J.C. Electroretinogram analysis of zebrafish retinal function across development. Doc. Ophthalmol. 2020. [CrossRef]

66. Van Epps, H.A.; Yim, C.M.; Hurley, J.B.; Brockerhoff, S.E. Investigations of photoreceptor synaptic transmission and light adaptation in the zebrafish visual mutant nrc. Investig. Ophthalmol. Vis. Sci. 2001, 42, 868-874.

67. Makhankov, Y.V.; Rinner, O.; Neuhauss, S.C.F. An inexpensive device for non-invasive electroretinography in small aquatic vertebrates. J. Neurosci. Methods 2004, 135, 205-210. [CrossRef]

68. Fleisch, V.C.; Jametti, T.; Neuhauss, S.C.F. Electroretinogram (ERG) measurements in larval zebrafish. Cold Spring Harb. Protoc. 2008, 3, 1-6. [CrossRef]

69. Brockerhoff, S.E.; Hurley, J.B.; Niemi, G.A.; Dowling, J.E. A new form of inherited red-blindness identified in zebrafish. J. Neurosci. 1997, 17, 4236-4242. [CrossRef]

70. Giarmarco, M.M.; Cleghorn, W.M.; Sloat, S.R.; Hurley, J.B.; Brockerhoff, S.E. Mitochondria maintain distinct Ca ${ }^{2+}$ pools in cone photoreceptors. J. Neurosci. 2017, 37, 2061-2072. [CrossRef]

71. Ma, E.Y.; Lewis, A.; Barabas, P.; Stearns, G.; Suzuki, S.; Krizaj, D.; Brockerhoff, S.E. Loss of Pde6 reduces cell body Ca ${ }^{2+}$ transients within photoreceptors. Cell Death Dis. 2013, 4, 1-10. [CrossRef]

72. Bisbach, C.M.; Hutto, R.A.; Poria, D.; Cleghorn, W.M.; Abbas, F.; Vinberg, F.; Kefalov, V.J.; Hurley, J.B.; Brockerhoff, S.E. Mitochondrial Calcium Uniporter (MCU) deficiency reveals an alternate path for $\mathrm{Ca}^{2+}$ uptake in photoreceptor mitochondria. Sci. Rep. 2020, 10, 1-19. [CrossRef]

73. Hutto, R.A.; Bisbach, C.M.; Abbas, F.; Brock, D.C.; Cleghorn, W.M.; Parker, E.D.; Bauer, B.H.; Ge, W.; Vinberg, F.; Hurley, J.B.; et al. Increasing $\mathrm{Ca}^{2+}$ in photoreceptor mitochondria alters metabolites, accelerates photoresponse recovery, and reveals adaptations to mitochondrial stress. Cell Death Differ. 2020, 27, 1067-1085. [CrossRef] [PubMed]

74. Rosen, J.N.; Sweeney, M.F.; Mably, J.D. Microinjection of zebrafish embryos to analyze gene function. J. Vis. Exp. 2009, 1-5. [CrossRef] [PubMed]

75. Kawakami, K.; Shima, A.; Kawakami, N. Identification of a functional transposase of the Tol2 element, an Ac-like element from the Japanese medaka fish, and its transposition in the zebrafish germ lineage. Proc. Natl. Acad. Sci. USA 2000, 97, 11403-11408. [CrossRef] [PubMed]

76. Kawakami, K. Tol2: A versatile gene transfer vector in vertebrates. Genome Biol. 2007, 8, 1-10. [CrossRef] [PubMed]

77. Thermes, V.; Grabher, C.; Ristoratore, F.; Bourrat, F.; Choulika, A.; Wittbrodt, J.; Joly, J.S. I-SceI meganuclease mediates highly efficient transgenesis in fish. Mech. Dev. 2002, 118, 91-98. [CrossRef]

78. Distel, M.; Wullimann, M.F.; Köster, R.W. Optimized Gal4 genetics for permanent gene expression mapping in zebrafish. Proc. Natl. Acad. Sci. USA 2009, 106, 13365-13370. [CrossRef] [PubMed]

79. Akitake, C.M.; Macurak, M.; Halpern, M.E.; Goll, M.G. Transgenerational analysis of transcriptional silencing in zebrafish. Dev. Biol. 2011, 352, 191-201. [CrossRef]

80. Goll, M.G.; Anderson, R.; Stainier, D.Y.R.; Spradling, A.C.; Halpern, M.E. Transcriptional silencing and reactivation in transgenic zebrafish. Genetics 2009, 182, 747-755. [CrossRef]

81. Jungke, P.; Hammer, J.; Hans, S.; Brand, M. Isolation of novel CreERT2-driver lines in zebrafish using an unbiased gene trap approach. PLoS ONE 2015, 10, 1-24. [CrossRef]

82. Kirchgeorg, L.; Felker, A.; van Oostrom, M.; Chiavacci, E.; Mosimann, C. Cre/lox-controlled spatiotemporal perturbation of FGF signaling in zebrafish. Dev. Dyn. 2018, 247, 1146-1159. [CrossRef]

83. Lin, H.J.; Lee, S.H.; Wu, J.L.; Duann, Y.F.; Chen, J.Y. Development of Cre-loxP technology in zebrafish to study the regulation of fish reproduction. Fish Physiol. Biochem. 2013, 39, 1525-1539. [CrossRef] [PubMed]

84. Mukherjee, K.; Liao, E.C. Generation and characterization of a zebrafish muscle specific inducible Cre line. Transgenic Res. 2018, 27, 559-569. [CrossRef] [PubMed]

85. Le, X.; Langenau, D.M.; Keefe, M.D.; Kutok, J.L.; Neuberg, D.S.; Zon, L.I. Heat shock-inducible Cre/Lox approaches to induce diverse types of tumors and hyperplasia in transgenic zebrafish. Proc. Natl. Acad. Sci. USA 2007, 104, 9410-9415. [CrossRef] [PubMed] 
86. Tabor, K.M.; Marquart, G.D.; Hurt, C.; Smith, T.S.; Geoca, A.K.; Bhandiwad, A.A.; Subedi, A.; Sinclair, J.L.; Rose, H.M.; Polys, N.F.; et al. Brain-wide cellular resolution imaging of Cre transgenic zebrafish lines for functional circuit-mapping. eLife 2019, 8, 1-21. [CrossRef] [PubMed]

87. Muto, A.; Orger, M.B.; Wehman, A.M.; Smear, M.C.; Kay, J.N.; Page-McCaw, P.S.; Gahtan, E.; Xiao, T.; Nevin, L.M.; Gosse, N.J.; et al. Forward genetic analysis of visual behavior in zebrafish. PLoS Genet. 2005, 1, e66. [CrossRef] [PubMed]

88. Doyon, Y.; McCammon, J.M.; Miller, J.C.; Faraji, F.; Ngo, C.; Katibah, G.E.; Amora, R.; Hocking, T.D.; Zhang, L.; Rebar, E.J.; et al Heritable targeted gene disruption in zebrafish using designed zinc-finger nucleases. Nat. Biotechnol. 2008, 26, 702-708. [CrossRef]

89. Zu, Y.; Tong, X.; Wang, Z.; Liu, D.; Pan, R.; Li, Z.; Hu, Y.; Luo, Z.; Huang, P.; Wu, Q.; et al. TALEN-mediated precise genome modification by homologous recombination in zebrafish. Nat. Methods 2013, 10, 329-331. [CrossRef]

90. Hwang, W.Y.; Fu, Y.; Reyon, D.; Maeder, M.L.; Tsai, S.Q.; Sander, J.D.; Peterson, R.T.; Yeh, J.R.J.; Joung, J.K. Efficient genome editing in zebrafish using a CRISPR-Cas system. Nat. Biotechnol. 2013, 31, 227-229. [CrossRef]

91. Doench, J.G.; Fusi, N.; Sullender, M.; Hegde, M.; Vaimberg, E.W.; Donovan, K.F.; Smith, I.; Tothova, Z.; Wilen, C.; Orchard, R.; et al. Optimized sgRNA design to maximize activity and minimize off-target effects of CRISPR-Cas9. Nat. Biotechnol. 2016, 34, 184-191. [CrossRef]

92. Ran, F.A.; Hsu, P.D.; Lin, C.Y.; Gootenberg, J.S.; Konermann, S.; Trevino, A.E.; Scott, D.A.; Inoue, A.; Matoba, S.; Zhang, Y.; et al. Double nicking by RNA-guided CRISPR Cas9 for enhanced genome editing specificity. Cell 2013, 154, 1380-1389. [CrossRef]

93. Maruyama, T.; Dougan, S.K.; Truttmann, M.C.; Bilate, A.M.; Ingram, J.R.; Ploegh, H.L. Increasing the efficiency of precise genome editing with CRISPR-Cas9 by inhibition of nonhomologous end joining. Nat. Biotechnol. 2015, 33, 538-542. [CrossRef] [PubMed]

94. Kocak, D.D.; Josephs, E.A.; Bhandarkar, V.; Adkar, S.S.; Kwon, J.B.; Gersbach, C.A. Increasing the specificity of CRISPR systems with engineered RNA secondary structures. Nat. Biotechnol. 2019, 37, 657-666. [CrossRef] [PubMed]

95. Kassahn, K.S.; Dang, V.T.; Wilkins, S.J.; Perkins, A.C.; Ragan, M.A. Evolution of gene function and regulatory control after whole-genome duplication: Comparative analyses in vertebrates. Genome Res. 2009, 19, 1404-1418. [CrossRef] [PubMed]

96. Schlegel, D.K.; Glasauer, S.M.K.; Mateos, J.M.; Barmettler, G.; Ziegler, U.; Neuhauss, S.C.F. A new zebrafish model for CACNA2D4dysfunction. Investig. Ophthalmol. Vis. Sci. 2019, 60, 5124-5135. [CrossRef]

97. Jia, S.; Muto, A.; Orisme, W.; Henson, H.E.; Parupalli, C.; Ju, B.; Baier, H.; Taylor, M.R. Zebrafish cacna1fa is required for cone photoreceptor function and synaptic ribbon formation. Hum. Mol. Genet. 2014, 23, 2981-2994. [CrossRef] [PubMed]

98. Seiler, C.; Finger-Baier, K.C.; Rinner, O.; Makhankov, Y.V.; Schwarz, H.; Neuhauss, S.C.F.; Nicolson, T. Duplicated genes with split functions: Independent roles of protocadherin 15 orthologues in zebrafish hearing and vision. Development 2005, 132, 615-623. [CrossRef]

99. Hitchcock, P.F.; Raymond, P.A. The teleost retina as a model for developmental and regeneration biology. Zebrafish 2004, 1, 257-271. [CrossRef]

100. Wan, J.; Ramachandran, R.; Goldman, D. HB-EGF is necessary and sufficient for Müller glia dedifferentiation and retina regeneration. Dev. Cell 2012, 22, 334-347. [CrossRef]

101. Ramachandran, R.; Zhao, X.F.; Goldman, D. Insm1a-mediated gene repression is essential for the formation and differentiation of Müller glia-derived progenitors in the injured retina. Nat. Cell Biol. 2012, 14, 1013-1023. [CrossRef]

102. Meyers, J.R.; Hu, L.; Moses, A.; Kaboli, K.; Papandrea, A.; Raymond, P.A. $\beta$-catenin/Wnt signaling controls progenitor fate in the developing and regenerating zebrafish retina. Neural Dev. 2012, 7, 1-17. [CrossRef]

103. Qin, Z.; Barthel, L.K.; Raymond, P.A. Genetic evidence for shared mechanisms of epimorphic regeneration in zebrafish. Proc. Natl. Acad. Sci. USA 2009, 106, 9310-9315. [CrossRef]

104. Bernardos, R.L.; Barthel, L.K.; Meyers, J.R.; Raymond, P.A. Late-stage neuronal progenitors in the retina are radial Müller glia that function as retinal stem cells. J. Neurosci. 2007, 27, 7028-7040. [CrossRef] [PubMed]

105. Penn, J.S. Effects of continuous light on the retina of a fish, Notemigonus crysoleucas. J. Comp. Neurol. 1985, 238, 121-127. [CrossRef] [PubMed]

106. Shahinfar, S.; Edward, D.P.; Tso, M.O. A pathological study of photoreceptor cell death in retinal photic injury. Curr. Eye Res. 1991, 10, 47-59. [CrossRef] [PubMed]

107. Thummel, R.; Kassen, S.C.; Enright, J.M.; Nelson, C.M.; Montgomery, J.E.; Hyde, D.R. Characterization of Müller glia and neuronal progenitors during adult zebrafish retinal regeneration. Exp. Eye Res. 2008, 87, 433-444. [CrossRef] [PubMed]

108. Vihtelic, T.S.; Soverly, J.E.; Kassen, S.C.; Hyde, D.R. Retinal regional differences in photoreceptor cell death and regeneration in light-lesioned albino zebrafish. Exp. Eye Res. 2006, 82, 558-575. [CrossRef]

109. Dunn, F.A. Photoreceptor ablation initiates the immediate loss of glutamate receptors in postsynaptic bipolar cells in retina. J. Neurosci. 2015, 35, 2423-2431. [CrossRef]

110. Winkler, B.S. Relative inhibitory effects of ATP depletion, ouabain and calcium on retinal photoreceptors. Exp. Eye Res. 1983, 36, 581-594. [CrossRef]

111. Fimbel, S.M.; Montgomery, J.E.; Burket, C.T.; Hyde, D.R. Regeneration of inner retinal neurons after intravitreal injection of ouabain in zebrafish. J. Neurosci. 2007, 27, 1712-1724. [CrossRef]

112. Maier, W.; Wolburg, H. Regeneration of the goldfish retina after exposure to different doses of ouabain. Cell Tissue Res. 1979, 202, 99-118. [CrossRef]

113. Terracjni, B.; Testa, M.C. Carcinogenicity of a single administration of N-nitrosomethylurea: A comparison between newborn and 5-week-old mice and rats. Br. J. Cancer 1970, 24, 588-598. [CrossRef] [PubMed] 
114. Wurdeman, R.L.; Church, K.M.; Gold, B. DNA methylation by N-methyl-N-nitrosourea, N-methyl-N'-nitro-N-nitrosoguanidine, $\mathrm{N}$-nitroso(1-acetoxyethyl)methylamine and diazomethane: Mechanism for the formation of N7-methylguanine in sequencecharacterized 5'-32P-end-labeled DNA. J. Am. Chem. Soc. 1989, 111, 6408-6412. [CrossRef]

115. Tappeiner, C.; Balmer, J.; Iglicki, M.; Schuerch, K.; Jazwinska, A.; Enzmann, V.; Tschopp, M. Characteristics of rod regeneration in a novel zebrafish retinal degeneration model using N-methyl-N-nitrosourea (MNU). PLoS ONE 2013, 8, 4-11. [CrossRef] [PubMed]

116. Nagar, S.; Krishnamoorthy, V.; Cherukuri, P.; Jain, V.; Dhingra, N.K. Early remodeling in an inducible animal model of retinal degeneration. Neuroscience 2009, 160, 517-529. [CrossRef] [PubMed]

117. Zulliger, R.; Lecaudé, S.; Eigeldinger-Berthou, S.; Wolf-Schnurrbusch, U.E.K.; Enzmann, V. Caspase-3-independent photoreceptor degeneration by N-methyl-N-nitrosourea (MNU) induces morphological and functional changes in the mouse retina. Graefe's Arch. Clin. Exp. Ophthalmol. 2011, 249, 859-869. [CrossRef]

118. Cao, R.; Jensen, L.D.E.; Söll, I.; Hauptmann, G.; Cao, Y. Hypoxia-induced retinal angiogenesis in zebrafish as a model to study retinopathy. PLoS ONE 2008, 3, 1-9. [CrossRef]

119. Nasevicius, A.; Ekker, S.C. Effective targeted gene "knockdown" in zebrafish. Nat. Genet. 2000, 26, 216-220. [CrossRef]

120. Draper, B.W.; Morcos, P.A.; Kimmel, C.B. Inhibition of zebrafish fgf8 pre-mRNA splicing with morpholino oligos: A quantifiable method for gene knockdown. Genesis 2001, 30, 154-156. [CrossRef]

121. Kok, F.O.; Shin, M.; Ni, C.W.; Gupta, A.; Grosse, A.S.; vanImpel, A.; Kirchmaier, B.C.; Peterson-Maduro, J.; Kourkoulis, G.; Male, I.; et al. Reverse genetic screening reveals poor correlation between morpholino-induced and mutant phenotypes in zebrafish. Dev. Cell 2015, 32, 97-108. [CrossRef]

122. Rossi, A.; Kontarakis, Z.; Gerri, C.; Nolte, H.; Hölper, S.; Krüger, M.; Stainier, D.Y.R. Genetic compensation induced by deleterious mutations but not gene knockdowns. Nature 2015, 524, 230-233. [CrossRef]

123. Morris, A.C.; Schroeter, E.H.; Bilotta, J.; Wong, R.O.; Fadool, J.M. Cone survival despite rod degeneration in XOPS-mCFP transgenic zebrafish. Investig. Ophthalmol. Vis. Sci. 2005, 46, 4762-4771. [CrossRef] [PubMed]

124. Curado, S.; Stainier, D.Y.; Anderson, R.M. Nitroreductase-mediated cell/tissue ablation in zebrafish: A spatially and temporally controlled ablation method with applications in developmental and regeneration studies. Nat. Protoc. 2008, 3, 948-954. [CrossRef] [PubMed]

125. Fraser, B.; DuVal, M.G.; Wang, H.; Allison, W.T. Regeneration of cone photoreceptors when cell ablation is primarily restricted to a particular cone subtype. PLoS ONE 2013, 8, e55410. [CrossRef] [PubMed]

126. Montgomery, J.E.; Parsons, M.J.; Hyde, D.R. A novel model of retinal ablation demonstrate that the extent of rod cell death regulates the origin of the regenerated zebrafish rod photoreceptors. J. Comp. Neurol. 2010, 518, 800-814. [CrossRef] [PubMed]

127. Yoshimatsu, T.; D’Orazi, F.D.; Gamlin, C.R.; Suzuki, S.C.; Suli, A.; Kimelman, D.; Raible, D.W.; Wong, R.O. Presynaptic partner selection during retinal circuit reassembly varies with timing of neuronal regeneration in vivo. Nat. Commun. 2016, 7, 1-10. [CrossRef]

128. White, D.T.; Sengupta, S.; Saxena, M.T.; Xu, Q.; Hanes, J.; Ding, D.; Ji, H.; Mumm, J.S. Immunomodulation-accelerated neuronal regeneration following selective rod photoreceptor cell ablation in the zebrafish retina. Proc. Natl. Acad. Sci. USA 2017, 114, E3719-E3728. [CrossRef]

129. D'Orazi, F.D.; Suzuki, S.C.; Darling, N.; Wong, R.O.; Yoshimatsu, T. Conditional and biased regeneration of cone photoreceptor types in the zebrafish retina. J. Comp. Neurol. 2020, 528, 2816-2830. [CrossRef]

130. Hanovice, N.J.; Leach, L.L.; Slater, K.; Gabriel, A.E.; Romanovicz, D.; Shao, E.; Collery, R.; Burton, E.A.; Lathrop, K.L.; Link, B.A.; et al. Regeneration of the zebrafish retinal pigment epithelium after widespread genetic ablation. PLoS Genet. 2019, 15, 1-35. [CrossRef]

131. Dryja, T.P.; McGee, T.L.; Reichel, E.; Hahn, L.; Cowley, G.S.; Yandell, D.W.; Sandberg, M.A.; Berson, E.L. A point mutation of the rhodopsin gene in one form of retinitis pigmentosa. Nature 1990, 343, 364-366. [CrossRef]

132. Sullivan, L.S.; Bowne, S.J.; Birch, D.G.; Hughbanks-Wheaton, D.; Heckenlively, J.R.; Lewis, R.A.; Garcia, C.A.; Ruiz, R.S.; Blanton, S.H.; Northrup, H.; et al. Prevalence of disease-causing mutations in families with autosomal dominant retinitis pigmentosa: A screen of known genes in 200 families. Investig. Ophthalmol. Vis. Sci. 2006, 47, 3052-3064. [CrossRef]

133. Parmeggiani, F.S.; Sorrentino, F.; Ponzin, D.; Barbaro, V.; Ferrari, S.; Di Iorio, E. Retinitis pigmentosa: Genes and disease mechanisms. Curr. Genom. 2011, 12, 238-249. [CrossRef] [PubMed]

134. Santhanam, A.; Shihabeddin, E.; Atkinson, J.A.; Nguyen, D.; Lin, Y.-P.; O’Brien, J. A zebrafish model of retinitis pigmentosa shows continuous degeneration and regeneration of rod photoreceptors. Cells 2020, 9, 2242. [CrossRef]

135. Sung, C.H.; Makino, C.; Baylor, D.; Nathans, J. A rhodopsin gene mutation responsible for autosomal dominant retinitis pigmentosa results in a protein that is defective in localization to the photoreceptor outer segment. J. Neurosci. 1994, 14, 5818-5833. [CrossRef] [PubMed]

136. Nakao, T.; Tsujikawa, M.; Notomi, S.; Ikeda, Y.; Nishida, K. The role of mislocalized phototransduction in photoreceptor cell death of retinitis pigmentosa. PLoS ONE 2012, 7. [CrossRef] [PubMed]

137. Vithana, E.N.; Abu-Safieh, L.; Allen, M.J.; Carey, A.; Papaioannou, M.; Chakarova, C.; Al-Maghtheh, M.; Ebenezer, N.D.; Willis, C.; Moore, A.T.; et al. A human homolog of yeast pre-mRNA splicing gene, PRP31, underlies autosomal dominant retinitis pigmentosa on chromosome 19q13.4 (RP11). Mol. Cell 2001, 8, 375-381. [CrossRef] 
138. Yin, J.; Brocher, J.; Fischer, U.; Winkler, C. Mutant Prpf31 causes pre-mRNA splicing defects and rod photoreceptor cell degeneration in a zebrafish model for retinitis pigmentosa. Mol. Neurodegener. 2011, 6, 56. [CrossRef]

139. Yang, Z.; Camp, N.J.; Sun, H.; Tong, Z.; Gibbs, D.; Cameron, D.J.; Chen, H.; Zhao, Y.; Pearson, E.; Li, X.; et al. A variant of the HTRA1 gene increases susceptibility to age-related macular degeneration. Science 2006, 314, 992-993. [CrossRef] [PubMed]

140. DeWan, A.; Liu, M.; Hartman, S.; Zhang, S.S.-M.; Liu, D.T.L.; Zhao, C.; Tam, P.O.S.T.; Chan, W.M.; Lam, D.S.C.; Snyder, M.; et al. HTRA1 promoter polymorphism in wet age-related macular degeneration. Science 2006, 314, 989-993. [CrossRef]

141. Jones, A.; Kumar, S.; Zhang, N.; Tong, Z.; Yang, J.H.; Watt, C.; Anderson, J.; Amrita; Fillerup, H.; McCloskey, M.; et al. Increased expression of multifunctional serine protease, HTRA1, in retinal pigment epithelium induces polypoidal choroidal vasculopathy in mice. Proc. Natl. Acad. Sci. USA 2011, 108, 14578-14583. [CrossRef]

142. Oura, Y.; Nakamura, M.; Takigawa, T.; Fukushima, Y.; Wakabayashi, T.; Tsujikawa, M.; Nishida, K. High-temperature requirement A 1 causes photoreceptor cell death in zebrafish disease models. Am. J. Pathol. 2018, 188, 2729-2744. [CrossRef]

143. Collery, R.F.; Cederlund, M.L.; Kennedy, B.N. Transgenic zebrafish expressing mutant human RETGC-1 exhibit aberrant cone and rod morphology. Exp. Eye Res. 2013, 108, 120-128. [CrossRef] [PubMed]

144. Link, B.A.; Collery, R.F. Zebrafish models of retinal disease. Annu. Rev. Vis. Sci. 2015, 1, 125-153. [CrossRef] [PubMed]

145. Angueyra, J.M.; Kindt, K.S. Leveraging zebrafish to study retinal degenerations. Front. Cell Dev. Biol. 2018, 6, 1-19. [CrossRef] [PubMed]

146. Chhetri, J.; Jacobson, G.; Gueven, N. Zebrafish-on the move towards ophthalmological research. Eye 2014, 28, 367-380. [CrossRef] [PubMed]

147. Gross, J.M.; Perkins, B.D. Zebrafish mutants as models for congenital ocular disorders in humans. Mol. Reprod. Dev. 2008, 75, 547-555. [CrossRef] [PubMed]

148. Morris, A.C. The genetics of ocular disorders: Insights from the zebrafish. Birth Defects Res. Part. C Embryo Today Rev. 2011, 93, 215-228. [CrossRef]

149. Athanasiou, D.; Aguila, M.; Bellingham, J.; Li, W.; McCulley, C.; Reeves, P.J.; Cheetham, M.E. The molecular and cellular basis of rhodopsin retinitis pigmentosa reveals potential strategies for therapy. Prog. Retin. Eye Res. 2018, 62, 1-23. [CrossRef]

150. Zelinka, C.P.; Sotolongo-Lopez, M.; Fadool, J.M. Targeted disruption of the endogenous zebrafish rhodopsin locus as models of rapid rod photoreceptor degeneration. Mol. Vis. 2018, 24, 587-602.

151. Eroglu, A.U.; Mulligan, T.S.; Zhang, L.; White, D.T.; Sengupta, S.; Nie, C.; Lu, N.Y.; Qian, J.; Xu, L.; Pei, W.; et al. Multiplexed CRISPR/Cas9 targeting of genes implicated in retinal regeneration and degeneration. Front. Cell Dev. Biol. $2018,6$. [CrossRef]

152. Schwahn, U.; Lenzner, S.; Dong, J.; Feil, S.; Hinzmann, B.; Van Duijnhoven, G.; Kirschner, R.; Hemberger, M.; Bergen, A.A.B.; Rosenberg, T.; et al. Positional cloning of the gene for X-linked retinitis pigmentosa 2. Nat. Genet. 1998, 19, 327-332. [CrossRef]

153. Hurd, T.W.; Fan, S.; Margolis, B.L. Localization of retinitis pigmentosa 2 to cilia is regulated by importin $\beta 2$. J. Cell Sci. 2011, 124, 718-726. [CrossRef] [PubMed]

154. Schwarz, N.; Hardcastle, A.J.; Cheetham, M.E. Arl3 and RP2 mediated assembly and traffic of membrane associated cilia proteins. Vis. Res. 2012, 75, 2-4. [CrossRef] [PubMed]

155. Evans, R.J.; Schwarz, N.; Nagel-Wolfrum, K.; Wolfrum, U.; Hardcastle, A.J.; Cheetham, M.E. The retinitis pigmentosa protein RP2 links pericentriolar vesicle transport between the Golgi and the primary cilium. Hum. Mol. Genet. 2010, 19, 1358-1367. [CrossRef] [PubMed]

156. Liu, F.; Chen, J.; Yu, S.; Raghupathy, R.K.; Liu, X.; Qin, Y.; Li, C.; Huang, M.; Liao, S.; Wang, J.; et al. Knockout of RP2 decreases GRK1 and rod transducin subunits and leads to photoreceptor degeneration in zebrafish. Hum. Mol. Genet. 2015, 24, 4648-4659. [CrossRef] [PubMed]

157. Tuson, M.; Marfany, G.; Gonzàlez-Duarte, R. Mutation of CERKL, a novel human ceramide kinase gene, causes autosomal recessive retinitis pigmentosa (RP26). Am. J. Hum. Genet. 2004, 74, 128-138. [CrossRef]

158. Yu, S.; Li, C.; Biswas, L.; Hu, X.; Liu, F.; Reilly, J.; Liu, X.; Liu, Y.; Huang, Y.; Lu, Z.; et al. CERKL gene knockout disturbs photoreceptor outer segment phagocytosis and causes rod-cone dystrophy in zebrafish. Hum. Mol. Genet. 2017, 26, 2335-2345. [CrossRef]

159. Cogné, B.; Latypova, X.; Senaratne, L.D.S.; Martin, L.; Koboldt, D.C.; Kellaris, G.; Fievet, L.; Le Meur, G.; Caldari, D.; Debray, D. Mutations in the kinesin-2 motor KIF3B cause an autosomal-dominant ciliopathy. Am. J. Hum. Genet. 2020, 106, 893-904. [CrossRef]

160. Zhao, C.; Omori, Y.; Brodowska, K.; Kovach, P.; Malicki, J. Kinesin-2 family in vertebrate ciliogenesis. Proc. Natl. Acad. Sci. USA 2012, 109, 2388-2393. [CrossRef]

161. Feng, D.; Chen, Z.; Yang, K.; Miao, S.; Xu, B.; Kang, Y.; Xie, H.; Zhao, C. The cytoplasmic tail of rhodopsin triggers rapid rod degeneration in kinesin-2 mutants. J. Biol. Chem. 2017, 292, 1735-17386. [CrossRef]

162. Dryja, T.P.; Adams, S.M.; Grimsby, J.L.; McGee, T.L.; Hong, D.H.; Li, T.; Andréasson, S.; Berson, E.L. Null RPGRIP1 alleles in patients with Leber congenital amaurosis. Am. J. Hum. Genet. 2001, 68, 1295-1298. [CrossRef]

163. Hameed, A.; Abid, A.; Aziz, A.; Ismail, M.; Mehdi, S.Q.; Khaliq, S. Evidence of RPGRIP1 gene mutations associated with recessive cone-rod dystrophy. J. Med. Genet. 2003, 40, 616-619. [CrossRef] [PubMed] 
164. Booij, J.C.; Florijn, R.J.; ten Brink, J.B.; Loves, W.; Meire, F.; van Schooneveld, M.J.; de Jong, P.T.; Bergen, A.A. Identification of mutations in the AIPL1, CRB1, GUCY2D, RPE65, and RPGRIP1 genes in patients with juvenile retinitis pigmentosa. J. Med. Genet. 2005, 42, 1-8. [CrossRef] [PubMed]

165. Mavlyutov, T.A.; Zhao, H.; Ferreira, P.A. Species-specific subcellular localization of RPGR and RPGRIP isoforms: Implications for the phenotypic variability of congenital retinopathies among species. Hum. Mol. Genet. 2002, 11, 1899-1907. [CrossRef] [PubMed]

166. Raghupathy, R.K.; Zhang, X.; Liu, F.; Alhasani, R.H.; Biswas, L.; Akhtar, S.; Pan, L.; Moens, C.B.; Li, W.; Liu, M.; et al. Rpgrip1 is required for rod outer segment development and ciliary protein trafficking in zebrafish. Sci. Rep. 2017, 7, 1-14. [CrossRef]

167. Davidson, A.E.; Sergouniotis, P.I.; Mackay, D.S.; Wright, G.A.; Waseem, N.H.; Michaelides, M.; Holder, G.E.; Robson, A.G.; Moore, A.T.; Plagnol, V.; et al. RP1L1 variants are associated with a spectrum of inherited retinal diseases including retinitis pigmentosa and occult macular dystrophy. Hum. Mutat. 2013, 34, 506-514. [CrossRef]

168. Noel, N.C.L.; MacDonald, I.M. RP1L1 and inherited photoreceptor disease: A review. Surv. Ophthalmol. 2020, 65, 725-739. [CrossRef]

169. Akahori, M.; Tsunoda, K.; Miyake, Y.; Fukuda, Y.; Ishiura, H.; Tsuji, S.; Usui, T.; Hatase, T.; Nakamura, M.; Ohde, H.; et al. Dominant mutations in RP1L1 are responsible for occult macular dystrophy. Am. J. Hum. Genet. 2010, 87, 424-429. [CrossRef]

170. Noel, N.C.L.; Nadolski, N.J.; Hocking, J.C.; Macdonald, I.M.; Allison, W.T. Progressive photoreceptor dysfunction and age-related macular degeneration-like features in rp111 mutant zebrafish. Cells 2020, 9, 2214. [CrossRef]

171. El-Amraoui, A.; Sahly, I.; Picaud, S.; Sahel, J.; Abitbol, M.; Petit, C. Human Usher 1B/mouse shaker-1: The retinal phenotype discrepancy explained by the presence/absence of myosin VIIA in the photoreceptor cells. Hum. Mol. Genet. 1996, 5, 1171-1178. [CrossRef]

172. Zina, Z.B.; Masmoudi, S.; Ayadi, H.; Chaker, F.; Ghorbel, A.M.; Drira, M.; Petit, C. From DFNB2 to usher syndrome: Variable expressivity of the same disease. Am. J. Med. Genet. 2001, 101, 181-183. [CrossRef]

173. Weil, D.; Küssel, P.; Blanchard, S.; Lévy, G.; Levi-Acobas, F.; Drira, M.; Ayadi, H.; Petit, C. The autosomal recessive isolated deafness, DFNB2, and the Usher 1B syndrome are allelic defects of the myosin-VIIA gene. Nat. Genet. 1997, 16, 191-193. [CrossRef] [PubMed]

174. Wasfy, M.M.; Matsui, J.I.; Miller, J.; Dowling, J.E.; Perkins, B.D. Myosin 7aa-/- mutant zebrafish show mild photoreceptor degeneration and reduced electroretinographic responses. Exp. Eye Res. 2014, 122, 65-76. [CrossRef] [PubMed]

175. Eudy, J.D.; Weston, M.D.; Yao, S.F.; Hoover, D.M.; Rehm, H.L.; Ma-Edmonds, M.; Yan, D.; Ahmad, I.; Cheng, J.J.; Ayuso, C.; et al. Mutation of a gene encoding a protein with extracellular matrix motifs in Usher syndrome type IIa. Science 1998, 280, $1753-1757$. [CrossRef] [PubMed]

176. van Wijk, E.; Pennings, R.J.E.; te Brinke, H.; Claassen, A.; Yntema, H.G.; Hoefsloot, L.H.; Cremers, F.P.M.; Cremers, W.R.J.; Kremer, H. Identification of 51 Novel Exons of the Usher Syndrome Type 2A (USH2A) Gene That Encode Multiple Conserved Functional Domains and That Are Mutated in Patients with Usher Syndrome Type II. Am. J. Hum. Genet. 2004, 74, 738-744. [CrossRef] [PubMed]

177. Han, S.; Liu, X.; Xie, S.; Gao, M.; Liu, F.; Yu, S.; Sun, P.; Wang, C.; Archacki, S.; Lu, Z.; et al. Knockout of ush2a gene in zebrafish causes hearing impairment and late onset rod-cone dystrophy. Hum. Genet. 2018, 137, 779-794. [CrossRef]

178. Dona, M.; Slijkerman, R.; Lerner, K.; Broekman, S.; Wegner, J.; Howat, T.; Peters, T.; Hetterschijt, L.; Boon, N.; de Vrieze, E.; et al. Usherin defects lead to early-onset retinal dysfunction in zebrafish. Exp. Eye Res. 2018, 173, 148-159. [CrossRef]

179. Morris, A.C.; Forbes-Osborne, M.A.; Pillai, L.S.; Fadool, J.M. Microarray analysis of XOPS-mCFP zebrafish retina identifies genes associated with rod photoreceptor degeneration and regeneration. Investig. Ophthalmol. Vis. Sci. 2011, 52, 2255-2266. [CrossRef]

180. Coomer, C.E.; Wilson, S.G.; Titialii-Torres, K.F.; Bills, J.D.; Krueger, L.A.; Petersen, R.A.; Turnbaugh, E.M.; Janesch, E.L.; Morris, A.C. Her9/Hes4 is required for retinal photoreceptor development, maintenance, and survival. Sci. Rep. 2020, 10, 1-20. [CrossRef]

181. Sukumaran, S.; Perkins, B.D. Early defects in photoreceptor outer segment morphogenesis in zebrafish ift 57 , ift 88 and ift 172 intraflagellar transport mutants. Vis. Res. 2009, 49, 479-489. [CrossRef]

182. Doerre, G.; Malicki, J. Genetic analysis of photoreceptor cell development in the zebrafish retina. Mech. Dev. 2002, 110, 125-138. [CrossRef]

183. Tsujikawa, M.; Malicki, J. Intraflagellar transport genes are essential for differentiation and survival of vertebrate sensory neurons. Neuron 2004, 42, 703-716. [CrossRef]

184. Krock, B.L.; Perkins, B.D. The intraflagellar transport protein IFT57 is required for cilia maintenance and regulates IFT-particlekinesin-II dissociation in vertebrate photoreceptors. J. Cell Sci. 2008, 121, 1907-1915. [CrossRef] [PubMed]

185. Lee, C.; Wallingford, J.B.; Gross, J.M. Cluap1 is essential for ciliogenesis and photoreceptor maintenance in the vertebrate eye. Investig. Ophthalmol. Vis. Sci. 2014, 55, 4585-4592. [CrossRef] [PubMed]

186. Gross, J.M.; Perkins, B.D.; Amsterdam, A.; Egaña, A.; Darland, T.; Matsui, J.I.; Sciascia, S.; Hopkins, N.; Dowling, J.E. Identification of zebrafish insertional mutants with defects in visual system development and function. Genetics 2005, 170, $245-261$. [CrossRef] [PubMed]

187. Boubakri, M.; Chaya, T.; Hirata, H.; Kajimura, N.; Kuwahara, R.; Ueno, A.; Malicki, J.; Furukawa, T.; Omori, Y. Loss of ift122, a retrograde intraflagellar transport (IFT) complex component, leads to slow, progressive photoreceptor degeneration due to inefficient opsin transport. J. Biol. Chem. 2016, 291, 24465-24474. [CrossRef] [PubMed]

188. Pooranachandran, N.; Malicki, J.J. Unexpected roles for ciliary kinesins and intraflagellar transport proteins. Genetics 2016, 203, 771-785. [CrossRef] [PubMed] 
189. Raghupathy, R.K.; Zhang, X.; Alhasani, R.H.; Zhou, X.; Mullin, M.; Reilly, J.; Li, W.; Liu, M.; Shu, X. Abnormal photoreceptor outer segment development and early retinal degeneration in kif3a mutant zebrafish. Cell Biochem. Funct. 2016, 34, 429-440. [CrossRef]

190. Burgalossi, A.; Jung, S.; Meyer, G.; Jockusch, W.J.; Jahn, O.; Taschenberger, H.; O'Connor, V.M.; Nishiki, T.-i.; Takahashi, M.; Brose, N.; et al. SNARE protein recycling by $\alpha$ SNAP and $\beta S N A P$ supports synaptic vesicle priming. Neuron 2010, $68,473-487$. [CrossRef]

191. Nishiwaki, Y.; Yoshizawa, A.; Kojima, Y.; Oguri, E.; Nakamura, S.; Suzuki, S.; Yuasa-Kawada, J.; Kinoshita-Kawada, M.; Mochizuki, T.; Masai, I. The BH3-only SNARE BNip1 mediates photoreceptor apoptosis in response to vesicular fusion defects. Dev. Cell 2013, 25, 374-387. [CrossRef]

192. Nishiwaki, Y.; Komori, A.; Sagara, H.; Suzuki, E.; Manabe, T.; Hosoya, T.; Nojima, Y.; Wada, H.; Tanaka, H.; Okamoto, H.; et al. Mutation of cGMP phosphodiesterase $6 \alpha^{\prime}$-subunit gene causes progressive degeneration of cone photoreceptors in zebrafish. Mech. Dev. 2008, 125, 932-946. [CrossRef]

193. Bujakowska, K.M.; Zhang, Q.; Siemiatkowska, A.M.; Liu, Q.; Place, E.; Falk, M.J.; Consugar, M.; Lancelot, M.E.; Antonio, A.; Lonjou, C.; et al. Mutations in IFT172 cause isolated retinal degeneration and Bardet-Biedl syndrome. Hum. Mol. Genet. 2015, 24, 230-242. [CrossRef] [PubMed]

194. Bachmann-Gagescu, R.; Phelps, I.G.; Dempsey, J.C.; Sharma, V.A.; Ishak, G.E.; Boyle, E.A.; Wilson, M.; Marques lourenço, C.; Arslan, M.; Shendure, J.; et al. KIAA0586 is mutated in Joubert syndrome. Hum. Mutat. 2015, 36, 831-835. [CrossRef] [PubMed]

195. Naharros, I.O.; Cristian, F.B.; Zang, J.; Gesemann, M.; Ingham, P.W.; Neuhauss, S.C.F.; Bachmann-Gagescu, R. The ciliopathy protein TALPID3/KIAA0586 acts upstream of Rab8 activation in zebrafish photoreceptor outer segment formation and maintenance. Sci. Rep. 2018, 8, 1-13. [CrossRef]

196. Edvardson, S.; Shaag, A.; Zenvirt, S.; Erlich, Y.; Hannon, G.J.; Shanske, A.L.; Gomori, J.M.; Ekstein, J.; Elpeleg, O. Joubert syndrome 2 (JBTS2) in Ashkenazi Jews is associated with a TMEM216 mutation. Am. J. Hum. Genet. 2010, 86, 93-97. [CrossRef] [PubMed]

197. Valente, E.M.; Logan, C.V.; Mougou-Zerelli, S.; Lee, J.H.; Silhavy, J.L.; Brancati, F.; Iannicelli, M.; Travaglini, L.; Romani, S.; Illi, B.; et al. Mutations in TMEM216 perturb ciliogenesis and cause Joubert, Meckel and related syndromes. Nat. Genet. 2010, 42, 619-625. [CrossRef] [PubMed]

198. Liu, Y.; Cao, S.; Yu, M.; Hu, H. TMEM216 deletion causes mislocalization of cone opsin and rhodopsin and photoreceptor degeneration in zebrafish. Investig. Ophthalmol. Vis. Sci. 2020, 61, 1-12. [CrossRef] [PubMed]

199. Asai-Coakwell, M.; March, L.; Dai, X.H.; DuVal, M.; Lopez, I.; French, C.R.; Famulski, J.; De Baere, E.; Francis, P.J.; Sundaresan, P.; et al. Contribution of growth differentiation factor 6-dependent cell survival to early-onset retinal dystrophies. Hum. Mol. Genet. 2013, 22, 1432-1442. [CrossRef]

200. Nadolski, N.J.; Balay, S.D.; Wong, C.X.L.; Waskiewicz, A.J.; Hocking, J.C. Abnormal cone and rod photoreceptor morphogenesis in gdf6a mutant zebrafish. Investig. Ophthalmol. Vis. Sci. 2020, 61. [CrossRef]

201. Noor, A.; Windpassinger, C.; Patel, M.; Stachowiak, B.; Mikhailov, A.; Azam, M.; Irfan, M.; Siddiqui, Z.K.; Naeem, F.; Paterson, A.D.; et al. CC2D2A, encoding a coiled-coil and C2 domain protein, causes autosomal-recessive mental retardation with retinitis pigmentosa. Am. J. Hum. Genet. 2008, 82, 1011-1018. [CrossRef]

202. Ferland, R.J.; Eyaid, W.; Collura, R.V.; Tully, L.D.; Hill, R.S.; Al-Nouri, D.; Al-Rumayyan, A.; Topcu, M.; Gascon, G.; Bodell, A.; et al. Abnormal cerebellar development and axonal decussation due to mutations in AHI1 in Joubert syndrome. Nat. Genet. 2004, 36, 1008-1013. [CrossRef]

203. Cantagrel, V.; Silhavy, J.L.; Bielas, S.L.; Swistun, D.; Marsh, S.E.; Bertrand, J.Y.; Audollent, S.; Attié-Bitach, T.; Holden, K.R.; Dobyns, W.B.; et al. Mutations in the cilia gene ARL13B lead to the classical form of Joubert syndrome. Am. J. Hum. Genet. 2008, 83, 170-179. [CrossRef] [PubMed]

204. Bachmann-Gagescu, R.; Phelps, I.G.; Stearns, G.; Link, B.A.; Brockerhoff, S.E.; Moens, C.B.; Doherty, D. The ciliopathy gene cc2d2a controls zebrafish photoreceptor outer segment development through a role in Rab8-dependent vesicle trafficking. Hum. Mol. Genet. 2011, 20, 4041-4055. [CrossRef] [PubMed]

205. Lessieur, E.M.; Fogerty, J.; Gaivin, R.J.; Song, P.; Perkins, B.D. The ciliopathy gene ahi1 is required for zebrafish cone photoreceptor outer segment morphogenesis and survival. Investig. Ophthalmol. Vis. Sci. 2017, 58, 448-460. [CrossRef] [PubMed]

206. Song, P.; Dudinsky, L.; Fogerty, J.; Gaivin, R.; Perkins, B.D. Arl13b interacts with vangl2 to regulate cilia and photoreceptor outer segment length in zebrafish. Investig. Ophthalmol. Vis. Sci. 2016, 57, 4517-4526. [CrossRef] [PubMed]

207. Den Hollander, A.I.; Koenekoop, R.K.; Mohamed, M.D.; Arts, H.H.; Boldt, K.; Towns, K.V.; Sedmak, T.; Beer, M.; Nagel-Wolfrum, K.; McKibbin, M.; et al. Mutations in LCA5, encoding the ciliary protein lebercilin, cause Leber congenital amaurosis. Nat. Genet. 2007, 39, 889-895. [CrossRef]

208. Qu, Z.; Yimer, T.A.; Xie, S.; Wong, F.; Yu, S.; Liu, X.; Han, S.; Ma, J.; Lu, Z.; Hu, X.; et al. Knocking out lca5 in zebrafish causes cone-rod dystrophy due to impaired outer segment protein trafficking. Biochim. Biophys. Acta Mol. Basis Dis. 2019, 1865, $2694-2705$. [CrossRef]

209. Nishimura, D.Y.; Baye, L.M.; Perveen, R.; Searby, C.C.; Avila-Fernandez, A.; Pereiro, I.; Ayuso, C.; Valverde, D.; Bishop, P.N.; Manson, F.D.C.; et al. Discovery and functional analysis of a retinitis pigmentosa gene, C2ORF71. Am. J. Hum. Genet. 2010, 86, 686-695. [CrossRef]

210. Corral-Serrano, J.C.; Messchaert, M.; Dona, M.; Peters, T.A.; Kamminga, L.M.; Van Wijk, E.; Collin, R.W.J. C2orf71a/pcare1 is important for photoreceptor outer segment morphogenesis and visual function in zebrafish. Sci. Rep. 2018, 8, 1-10. [CrossRef] 
211. Abd El-Aziz, M.M.; Barragan, I.; O’Driscoll, C.A.; Goodstadt, L.; Prigmore, E.; Borrego, S.; Mena, M.; Pieras, J.I.; El-Ashry, M.F.; Safieh, L.A.; et al. EYS, encoding an ortholog of Drosophila spacemaker, is mutated in autosomal recessive retinitis pigmentosa. Nat. Genet. 2008, 40, 1285-1287. [CrossRef]

212. Collin, R.W.J.; Littink, K.W.; Klevering, B.J.; van den Born, L.I.; Koenekoop, R.K.; Zonneveld, M.N.; Blokland, E.A.W.; Strom, T.M.; Hoyng, C.B.; den Hollander, A.I.; et al. Identification of a $2 \mathrm{Mb}$ human ortholog of Drosophila eyes shut/spacemaker that Is mutated in patients with retinitis pigmentosa. Am. J. Hum. Genet. 2008, 83, 594-603. [CrossRef]

213. Katagiri, S.; Akahori, M.; Hayashi, T.; Yoshitake, K.; Gekka, T.; Ikeo, K.; Tsuneoka, H.; Iwata, T. Autosomal recessive cone-rod dystrophy associated with compound heterozygous mutations in the EYS gene. Doc. Ophthalmol. 2014, 128, 211-217. [CrossRef] [PubMed]

214. Alfano, G.; Kruczek, P.M.; Shah, A.Z.; Kramarz, B.; Jeffery, G.; Zelhof, A.C.; Bhattacharya, S.S. EYS is a protein associated with the ciliary axoneme in rods and cones. PLoS ONE 2016, 11, 1-20. [CrossRef] [PubMed]

215. Yu, M.; Liu, Y.; Li, J.; Natale, B.N.; Cao, S.; Wang, D.; Amack, J.D.; Hu, H. Eyes shut homolog is required for maintaining the ciliary pocket and survival of photoreceptors in zebrafish. Biol. Open 2016, 5, 1662-1673. [CrossRef] [PubMed]

216. Messchaert, M.; Dona, M.; Broekman, S.; Peters, T.A.; Corral-Serrano, J.C.; Slijkerman, R.W.N.; van Wijk, E.; Collin, R.W.J. Eyes shut homolog is important for the maintenance of photoreceptor morphology and visual function in zebrafish. PLoS ONE 2018, 13, 1-16. [CrossRef] [PubMed]

217. Lu, Z.; Hu, X.; Liu, F.; Soares, D.C.; Liu, X.; Yu, S.; Gao, M.; Han, S.; Qin, Y.; Li, C.; et al. Ablation of EYS in zebrafish causes mislocalisation of outer segment proteins, F-actin disruption and cone-rod dystrophy. Sci. Rep. 2017, 7, 1-12. [CrossRef]

218. Nishimura, D.Y.; Searby, C.C.; Carmi, R.; Elbedour, K.; Van Maldergem, L.; Fulton, A.B.; Lam, B.L.; Powell, B.R.; Swiderski, R.E.; Bugge, K.E.; et al. Positional cloning of a novel gene on chromosome 16q causing Bardet-Biedl syndrome (BBS2). Hum. Mol. Genet. 2001, 10, 865-874. [CrossRef]

219. Shevach, E.; Ali, M.; Mizrahi-Meissonnier, L.; McKibbin, M.; El-Asrag, M.; Watson, C.M.; Inglehearn, C.F.; Ben-Yosef, T.; Blumenfeld, A.; Jalas, C.; et al. Association between missense mutations in the BBS2 gene and nonsyndromic retinitis pigmentosa. Jama Ophthalmol. 2015, 133, 312-318. [CrossRef]

220. Song, P.; Fogerty, J.; Cianciolo, L.T.; Stupay, R.; Perkins, B.D. Cone photoreceptor degeneration and neuroinflammation in the zebrafish Bardet-Biedl syndrome 2 (bbs2) mutant does not lead to retinal regeneration. Front. Cell Dev. Biol. 2020, 8, 1-13. [CrossRef]

221. Sergouniotis, P.I.; Davidson, A.E.; Mackay, D.S.; Li, Z.; Yang, X.; Plagnol, V.; Moore, A.T.; Webster, A.R. Recessive mutations in KCNJ13, encoding an inwardly rectifying potassium channel subunit, cause leber congenital amaurosis. Am. J. Hum. Genet. 2011, 89, 183-190. [CrossRef]

222. Toms, M.; Burgoyne, T.; Tracey-White, D.; Richardson, R.; Dubis, A.M.; Webster, A.R.; Futter, C.; Moosajee, M. Phagosomal and mitochondrial alterations in RPE may contribute to KCNJ13 retinopathy. Sci. Rep. 2019, 9, 1-15. [CrossRef]

223. Xu, M.; Yamada, T.; Sun, Z.; Eblimit, A.; Lopez, I.; Wang, F.; Manya, H.; Xu, S.; Zhao, L.; Li, Y.; et al. Mutations in POMGNT1 cause non-syndromic retinitis pigmentosa. Hum. Mol. Genet. 2016, 25, 1479-1488. [CrossRef] [PubMed]

224. Liu, Y.; Yu, M.; Shang, X.; Nguyen, M.H.H.; Balakrishnan, S.; Sager, R.; Hu, H. Eyes shut homolog (EYS) interacts with matriglycan of O-mannosyl glycans whose deficiency results in EYS mislocalization and degeneration of photoreceptors. Sci. Rep. 2020, 10, 1-14. [CrossRef] [PubMed]

225. Xie, S.; Han, S.; Qu, Z.; Liu, F.; Li, J.; Yu, S.; Reilly, J.; Tu, J.; Liu, X.; Lu, Z.; et al. Knockout of Nr2e3 prevents rod photoreceptor differentiation and leads to selective L-/M-cone photoreceptor degeneration in zebrafish. Biochim. Biophys. Acta Mol. Basis Dis. 2019, 1865, 1273-1283. [CrossRef] [PubMed]

226. Oel, A.P.; Neil, G.N.; Dong, E.M.; Balay, S.D.; Collett, K.; Allison, W.T. Nrl is dispensable for specification of rod photoreceptors in adult zebrafish contrasting a deeply conserved requirement earlier in ontogeny. iScience 2020, 23. [CrossRef]

227. Maw, M.A.; Corbeil, D.; Koch, J.; Hellwig, A.; Wilson-Wheeler, J.C.; Bridges, R.J.; Kumaramanickavel, G.; John, S.; Nancarrow, D.; Röper, K.; et al. A frameshift mutation in prominin (mouse)-like 1 causes human retinal degeneration. Hum. Mol. Genet. 2000, 9 , 27-34. [CrossRef]

228. Zhang, Q.; Zulfiqar, F.; Xiao, X.; Riazuddin, S.A.; Ahmad, Z.; Caruso, R.; MacDonald, I.; Sieving, P.; Riazuddin, S.A.; Hejtmancik, J.F. Severe retinitis pigmentosa mapped to $4 \mathrm{p} 15$ and associated with a novel mutation in the PROM1 gene. Hum. Genet. 2007, 122, 293-299. [CrossRef]

229. Yang, Z.; Chen, Y.; Lillo, C.; Chien, J.; Yu, Z.; Michaelides, M.; Klein, M.; Howes, K.A.; Li, Y.; Kaminoh, Y.; et al. Mutant prominin 1 found in patients with macular degeneration disrupts photoreceptor disk morphogenesis in mice. J. Clin. Investig. 2008, 118, 2908-2916. [CrossRef]

230. Lu, Z.; Hu, X.; Reilly, J.; Jia, D.; Liu, F.; Yu, S.; Liu, X.; Xie, S.; Qu, Z.; Qin, Y.; et al. Deletion of the transmembrane protein Prom1b in zebrafish disrupts outer-segment morphogenesis and causes photoreceptor degeneration. J. Biol. Chem. 2019, $294,13953-13963$. [CrossRef]

231. Lessieur, E.M.; Song, P.; Nivar, G.C.; Piccillo, E.M.; Fogerty, J.; Rozic, R.; Perkins, B.D. Ciliary genes arl13b, ahi1 and cc2d2a differentially modify expression of visual acuity phenotypes but do not enhance retinal degeneration due to mutation of cep290 in zebrafish. PLoS ONE 2019, 14, 1-26. [CrossRef] 
232. Thiadens, A.A.H.J.; den Hollander, A.I.; Roosing, S.; Nabuurs, S.B.; Zekveld-Vroon, R.C.; Collin, R.W.J.; De Baere, E.; Koenekoop, R.K.; van Schooneveld, M.J.; Strom, T.M.; et al. Homozygosity mapping reveals PDE6C mutations in patients with early-onset cone photoreceptor disorders. Am. J. Hum. Genet. 2009, 85, 240-247. [CrossRef]

233. Sohocki, M.M.; Bowne, S.J.; Sullivan, L.S.; Blackshaw, S.; Cepko, C.L.; Payne, A.M.; Bhattacharya, S.S.; Khaliq, S.; Mehdi, S.Q.; Birch, D.G.; et al. Mutations in a new photoreceptor-pineal gene on 17p cause Leber congenital amaurosis. Nat. Genet. 2000, 24, 79-83. [CrossRef] [PubMed]

234. Sohocki, M.M.; Perrault, I.; Leroy, B.P.; Payne, A.M.; Dharmaraj, S.; Bhattacharya, S.S.; Kaplan, J.; Maumenee, I.H.; Koenekoop, R.; Meire, F.M.; et al. Prevalence of AIPL1 mutations in inherited retinal degenerative disease. Mol. Genet. Metab. 2000, 70, 142-150. [CrossRef] [PubMed]

235. Iribarne, M.; Nishiwaki, Y.; Nakamura, S.; Araragi, M.; Oguri, E.; Masai, I. Aipl1 is required for cone photoreceptor function and survival through the stability of Pde6c and Gc3 in zebrafish. Sci. Rep. 2017, 7, 1-13. [CrossRef] [PubMed]

236. Wycisk, K.A.; Zeitz, C.; Feil, S.; Wittmer, M.; Forster, U.; Neidhardt, J.; Wissinger, B.; Zrenner, E.; Wilke, R.; Kohl, S.; et al. Mutation in the auxiliary calcium-channel subunit CACNA2D4 causes autosomal recessive cone dystrophy. Am. J. Hum. Genet. 2006, 79, 973-977. [CrossRef] [PubMed]

237. Daly, C.; Shine, L.; Heffernan, T.; Deeti, S.; Reynolds, A.L.; O'Connor, J.J.; Dillon, E.T.; Duffy, D.J.; Kolch, W.; Cagney, G.; et al. A brain-derived neurotrophic factor mimetic is sufficient to restore cone photoreceptor visual function in an inherited blindness model. Sci. Rep. 2017, 7, 1-18. [CrossRef] [PubMed]

238. Vilardi, F.; Stephan, M.; Clancy, A.; Janshoff, A.; Schwappach, B. WRB and CAML are necessary and sufficient to mediate tail-anchored protein targeting to the ER membrane. PLoS ONE 2014, 9. [CrossRef]

239. Daniele, L.L.; Emran, F.; Lobo, G.P.; Gaivin, R.J.; Perkins, B.D. Mutation of wrb, a component of the guided entry of Tail-Anchored protein pathway, disrupts photoreceptor synapse structure and function. Investig. Ophthalmol. Vis. Sci. 2016, 57, 2942-2954 [CrossRef]

240. Lin, S.Y.; Vollrath, M.A.; Mangosing, S.; Shen, J.; Cardenas, E.; Corey, D.P. The zebrafish pinball wizard gene encodes WRB, a tail-anchored-protein receptor essential for inner-ear hair cells and retinal photoreceptors. J. Physiol. 2016, 594, 895-914. [CrossRef]

241. Kohl, S.; Baumann, B.; Rosenberg, T.; Kellner, U.; Lorenz, B.; Vadalà, M.; Jacobson, S.G.; Wissinger, B. Mutations in the cone photoreceptor G-protein $\alpha$-subunit gene GNAT2 in patients with achromatopsia. Am. J. Hum. Genet. 2002, 71, 422-425. [CrossRef]

242. Brockerhoff, S.E.; Rieke, F.; Matthews, H.R.; Taylor, M.R.; Kennedy, B.; Ankoudinova, I.; Niemi, G.A.; Tucker, C.L.; Xiao, M.; Cilluffo, M.C.; et al. Light stimulates a transducin-independent increase of cytoplasmic $\mathrm{Ca}^{2+}$ and suppression of current in cones from the zebrafish mutant nof. J. Neurosci. 2003, 23, 470-480. [CrossRef]

243. Bech-Hansen, N.T.; Naylor, M.J.; Maybaum, T.A.; Pearce, W.G.; Koop, B.; Fishman, G.A.; Mets, M.; Musarella, M.A.; Boycott, K.M. Loss-of-function mutations in a calcium-channel $\alpha 1$-subunit gene in Xp11.23 cause incomplete X-linked congenital stationary night blindness. Nat. Genet. 1998, 19, 264-267. [CrossRef]

244. Strom, T.M.; Nyakatura, G.; Apfelstedt-Sylla, E.; Hellebrand, H.; Lorenz, B.; Weber, B.H.F.; Wutz, K.; Gutwillinger, N.; Rüther, K.; Drescher, B.; et al. An L-type calcium-channel gene mutated in incomplete X-linked congenital stationary night blindness. Nat. Genet. 1998, 19, 260-263. [CrossRef] [PubMed]

245. Jalkanen, R.; Mänlyjärvi, M.; Tobias, R.; Isosomppi, J.; Sankila, E.M.; Alitalo, T.; Bech-Hansen, N.T. X linked cone-rod dystrophy, CORDX3, is caused by a mutation in the CACNA1F gene. J. Med. Genet. 2006, 43, 699-704. [CrossRef] [PubMed]

246. Baumann, L.; Gerstner, A.; Zong, X.; Biel, M.; Wahl-Schott, C. Functional characterization of the L-type Ca ${ }^{2+}$ channel Cav1.4 $\alpha 1$ from mouse retina. Investig. Ophthalmol. Vis. Sci. 2004, 45, 708-713. [CrossRef] [PubMed]

247. Van Epps, H.A.; Hayashi, M.; Lucast, L.; Stearns, G.W.; Hurley, J.B.; De Camilli, P.; Brockerhoff, S.E. The zebrafish nrc mutant reveals a role for the polyphosphoinositide phosphatase synaptojanin 1 in cone photoreceptor ribbon anchoring. J. Neurosci. 2004, 24, 8641-8650. [CrossRef]

248. Allwardt, B.A.; Lall, A.B.; Brockerhoff, S.E.; Dowling, J.E. Synapse formation is arrested in retinal photoreceptors of the zebrafish nrc mutant. J. Neurosci. 2001, 21, 2330-2342. [CrossRef]

249. Holzhausen, L.C.; Lewis, A.A.; Cheong, K.K.; Brockerhoff, S.E. Differential role for synaptojanin 1 in rod and cone photoreceptors. J. Comp. Neurol. 2009, 517, 633-644. [CrossRef]

250. Huang, D.F.; Wang, M.Y.; Yin, W.U.; Ma, Y.Q.; Wang, H.A.N.; Xue, T.; Ren, D.L.; Hu, B. Zebrafish lacking circadian gene per2 exhibit visual function deficiency. Front. Behav. Neurosci. 2018, 12, 1-10. [CrossRef]

251. Van Rooijen, E.; Voest, E.E.; Logister, I.; Bussmann, J.; Korving, J.; Van Eeden, F.J.; Giles, R.H.; Schulte-Merker, S. Von HippelLindau tumor suppressor mutants faithfully model pathological hypoxia-driven angiogenesis and vascular retinopathies in zebrafish. Dmm Dis. Model. Mech. 2010, 3, 343-353. [CrossRef]

252. Schori, C.; Agbaga, M.P.; Brush, R.S.; Ayyagari, R.; Grimm, C.; Samardzija, M. Elovl4 5-bp deletion does not accelerate cone photoreceptor degeneration in an all-cone mouse. PLoS ONE 2018, 13, 1-16. [CrossRef]

253. Zhao, L.; Zabel, M.K.; Wang, X.; Ma, W.; Shah, P.; Fariss, R.N.; Qian, H.; Parkhurst, C.N.; Gan, W.; Wong, W.T. Microglial phagocytosis of living photoreceptors contributes to inherited retinal degeneration. Embo Mol. Med. 2015, 7, 1179-1197. [CrossRef] [PubMed]

254. Sancho-Pelluz, J.; Alavi, M.V.; Sahaboglu, A.; Kustermann, S.; Farinelli, P.; Azadi, S.; Van Veen, T.; Romero, F.J.; Paquet-Durand, F.; Ekström, P. Excessive HDAC activation is critical for neurodegeneration in the rd1 mouse. Cell Death Dis. 2010, 1, 1-9. [CrossRef] [PubMed] 
255. Trifunović, D.; Arango-Gonzalez, B.; Comitato, A.; Barth, M.; del Amo, E.M.; Kulkarni, M.; Sahaboglu, A.; Hauck, S.M.; Urtti, A.; Arsenijevic, Y.; et al. HDAC inhibition in the cpfl1 mouse protects degenerating cone photoreceptors in vivo. Hum. Mol. Genet. 2016, 25, 4462-4472. [CrossRef] [PubMed]

256. Lai, J.I.; Leman, L.J.; Ku, S.; Vickers, C.J.; Olsen, C.A.; Montero, A.; Ghadiri, M.R.; Gottesfeld, J.M. Cyclic tetrapeptide HDAC inhibitors as potential therapeutics for spinal muscular atrophy: Screening with iPSC-derived neuronal cells. Bioorganic Med. Chem. Lett. 2017, 27, 3289-3293. [CrossRef]

257. Janczura, K.J.; Volmar, C.H.; Sartor, G.C.; Rao, S.J.; Ricciardi, N.R.; Lambert, G.; Brothers, S.P.; Wahlestedt, C. Inhibition of HDAC3 reverses Alzheimer's disease-related pathologies in vitro and in the 3xTg-AD mouse model. Proc. Natl. Acad. Sci. USA 2018, 115, E11148-E11157. [CrossRef]

258. Kawase, R.; Nishimura, Y.; Ashikawa, Y.; Sasagawa, S.; Murakami, S.; Yuge, M.; Okabe, S.; Kawaguchi, K.; Yamamoto, H.; Moriyuki, K.; et al. EP300 protects from light-induced retinopathy in zebrafish. Front. Pharm. 2016, 7, 1-13. [CrossRef]

259. D’Ydewalle, C.; Krishnan, J.; Chiheb, D.M.; Van Damme, P.; Irobi, J.; Kozikowski, A.P.; Berghe, P.V.; Timmerman, V.; Robberecht, W.; Van Den Bosch, L. HDAC6 inhibitors reverse axonal loss in a mouse model of mutant HSPB1-induced Charcot-Marie-Tooth disease. Nat. Med. 2011, 17, 968-974. [CrossRef]

260. Sundaramurthi, H.; Roche, S.L.; Grice, G.L.; Moran, A.; Dillion, E.T.; Campiani, G.; Nathan, J.A.; Kennedy, B.N. Selective histone deacetylase 6 inhibitors restore cone photoreceptor vision or outer segment morphology in zebrafish and mouse models of retinal blindness. Front. Cell Dev. Biol. 2020, 8. [CrossRef]

261. Leyk, J.; Daly, C.; Janssen-Bienhold, U.; Kennedy, B.N.; Richter-Landsberg, C. HDAC6 inhibition by tubastatin A is protective against oxidative stress in a photoreceptor cell line and restores visual function in a zebrafish model of inherited blindness. Cell Death Dis. 2017, 8, e3028. [CrossRef]

262. Kokel, D.; Bryan, J.; Laggner, C.; White, R.; Cheung, C.Y.J.; Mateus, R.; Healey, D.; Kim, S.; Werdich, A.A.; Haggarty, S.J.; et al. Rapid behavior-based identification of neuroactive small molecules in the zebrafish. Nat. Chem. Biol. 2010, 6, 231-237. [CrossRef]

263. Rihel, J.; Prober, D.A.; Arvanites, A.; Lam, K.; Zimmerman, S.; Jang, S.; Haggarty, S.J.; Kokel, D.; Rubin, L.L.; Peterson, R.T.; et al. Zebrafish behavioral profiling links drugs to biological targets and rest/wake regulation. Science 2010, 327, 348-352. [CrossRef] [PubMed]

264. Ganzen, L.; Ko, M.; Zhang, M.; Xie, R.; Chen, Y.; Zhang, L.; James, R.; Mumm, J.; van Rijn, R.; Zhong, W.; et al. Drug screening with zebrafish visual behavior identifies carvedilol as a potential treatment for retinitis pigmentosa. bioRxiv 2020. [CrossRef]

265. Viringipurampeer, I.A.; Shan, X.; Gregory-Evans, K.; Zhang, J.P.; Mohammadi, Z.; Gregory-Evans, C.Y. Rip3 knockdown rescues photoreceptor cell death in blind pde6c zebrafish. Cell Death Differ. 2014, 21, 665-675. [CrossRef]

266. Giridharan, V.V.; Thandavarayan, R.A.; Sato, S.; Ko, K.M.; Konishi, T. Prevention of scopolamine-induced memory deficits by schisandrin B, an antioxidant lignan from Schisandra chinensis in mice. Free Radic. Res. 2011, 45, 950-958. [CrossRef] [PubMed]

267. Ko, K.M.; Lam, B.Y.H. Schisandrin B protects against tert-butylhydroperoxide induced cerebral toxicity by enhancing glutathione antioxidant status in mouse brain. Mol. Cell. Biochem. 2002, 238, 181-186. [CrossRef] [PubMed]

268. Zhang, L.; Xiang, L.; Liu, Y.; Venkatraman, P.; Chong, L.; Cho, J.; Bonilla, S.; Jin, Z.B.; Pang, C.P.; Ko, K.M.; et al. A naturallyderived compound schisandrin $B$ enhanced light sensation in the pde6c zebrafish model of retinal degeneration. PLoS ONE 2016, 11, 1-19. [CrossRef]

269. Chen, N.; Chiu, P.Y.; Ko, K.M. Schisandrin B enhances cerebral mitochondrial antioxidant status and structural integrity, and protects against cerebral ischemia/reperfusion injury in rats. Biol. Pharm. Bull. 2008, 31, 1387-1391. [CrossRef]

270. Ji, X.; Shen, Y.; Guo, X. Isolation, structures, and bioactivities of the polysaccharides from Gynostemma pentaphyllum (Thunb.) Makino: A review. Biomed. Res. Int. 2018, 2018. [CrossRef]

271. Alhasani, R.H.; Zhou, X.; Biswas, L.; Li, X.; Reilly, J.; Zeng, Z.; Shu, X. Gypenosides attenuate retinal degeneration in a zebrafish retinitis pigmentosa model. Exp. Eye Res. 2020, 201, 108291. [CrossRef]

272. Deeti, S.; O'Farrell, S.; Kennedy, B.N. Early safety assessment of human oculotoxic drugs using the zebrafish visualmotor response. J. Pharm. Toxicol. Methods 2014, 69, 1-8. [CrossRef]

273. Vaché, C.; Besnard, T.; le Berre, P.; García-García, G.; Baux, D.; Larrieu, L.; Abadie, C.; Blanchet, C.; Bolz, H.J.; Millan, J.; et al. Usher syndrome type 2 caused by activation of an USH2A pseudoexon: Implications for diagnosis and therapy. Hum. Mutat. 2012, 33, 104-108. [CrossRef] [PubMed]

274. Slijkerman, R.; Goloborodko, A.; Broekman, S.; de Vrieze, E.; Hetterschijt, L.; Peters, T.; Gerits, M.; Kremer, H.; van Wijk, E. Poor splice-site recognition in a humanized zebrafish knockin model for the recurrent deep-intronic c.7595-2144A $>$ G mutation in USH2A. Zebrafish 2018, 15, 597-609. [CrossRef] [PubMed]

275. Slijkerman, R.; van Diepen, H.; Albert, S.; Dona, M.; Venselaar, H.; Zang, J.; Neuhauss, S.; Peters, T.; Broekman, S.; Pennings, R.; et al. Antisense oligonucleotide-based treatment of retinitis pigmentosa caused by mutations in USH2A exon 13. bioRxiv 2020. [CrossRef]

276. Baux, D.; Blanchet, C.; Hamel, C.; Meunier, I.; Larrieu, L.; Faugère, V.; Vaché, C.; Castorina, P.; Puech, B.; Bonneau, D.; et al. Enrichment of LOVD-USHbases with 152 USH2A genotypes defines an extensive mutational spectrum and highlights missense hotspots. Hum. Mutat. 2014, 35, 1179-1186. [CrossRef]

277. Cameron, D.A. Cellular proliferation and neurogenesis in the injured retina of adult zebrafish. Vis. Neurosci. 2000, 17, 789-797. [CrossRef] 
278. Wan, Y.; Almeida, A.D.; Rulands, S.; Chalour, N.; Muresan, L.; Wu, Y.; Simons, B.D.; He, J.; Harris, W.A. The ciliary marginal zone of the zebrafish retina: Clonal and time-lapse analysis of a continuously growing tissue. Development 2016, 143, $1099-1107$. [CrossRef]

279. Yurco, P.; Cameron, D.A. Responses of Muller glia to retinal injury in adult zebrafish. Vis. Res. 2005, 45, 991-1002. [CrossRef]

280. Marcucci, F.; Murcia-Belmonte, V.; Wang, Q.; Coca, Y.; Ferreiro-Galve, S.; Kuwajima, T.; Khalid, S.; Ross, M.E.; Mason, C.; Herrera, E. The ciliary margin zone of the mammalian retina generates retinal ganglion cells. Cell Rep. 2016, 17, 3153-3164. [CrossRef]

281. Bhatia, B.; Jayaram, H.; Singhal, S.; Jones, M.F.; Limb, G.A. Differences between the neurogenic and proliferative abilities of Müller glia with stem cell characteristics and the ciliary epithelium from the adult human eye. Exp. Eye Res. 2011, 93, 852-861. [CrossRef]

282. Ahmad, I.; Tang, L.; Pham, H. Identification of neural progenitors in the adult mammalian eye. Biochem. Biophys. Res. Commun. 2000, 270, 517-521. [CrossRef]

283. Bhatia, B.; Singhal, S.; Lawrence, J.M.; Khaw, P.T.; Limb, G.A. Distribution of Müller stem cells within the neural retina: Evidence for the existence of a ciliary margin-like zone in the adult human eye. Exp. Eye Res. 2009, 89, 373-382. [CrossRef] [PubMed]

284. Fleisch, V.C.; Fraser, B.; Allison, W.T. Investigating regeneration and functional integration of CNS neurons: Lessons from zebrafish genetics and other fish species. Biochim. Biophys. Acta Mol. Basis Dis. 2011, 1812, 364-380. [CrossRef] [PubMed]

285. Nagashima, M.; Barthel, L.K.; Raymond, P.A. A self-renewing division of zebrafish Muller glial cells generates neuronal progenitors that require N-cadherin to regenerate retinal neurons. Development 2013, 140, 4510-4521. [CrossRef]

286. Fausett, B.V.; Goldman, D. A role for alpha1 tubulin-expressing Muller glia in regeneration of the injured zebrafish retina. J. Neurosci. 2006, 26, 6303-6313. [CrossRef] [PubMed]

287. Otteson, D.C.; Hitchcock, P.F. Stem cells in the teleost retina: Persistent neurogenesis and injury-induced regeneration. Vis. Res. 2003, 43, 927-936. [CrossRef]

288. Ramachandran, R.; Fausett, B.V.; Goldman, D. Ascl1a regulates Müller glia dedifferentiation and retinal regeneration through a Lin-28-dependent, let-7 microRNA signalling pathway. Nat. Cell Biol. 2010, 12, 1101-1107. [CrossRef]

289. Nelson, C.M.; Ackerman, K.M.; O'Hayer, P.; Bailey, T.J.; Gorsuch, R.A.; Hyde, D.R. Tumor necrosis factor-alpha is produced by dying retinal neurons and is required for Müller glia proliferation during zebrafish retinal regeneration. J. Neurosci. 2013, 33, 6524-6539. [CrossRef]

290. Lawrence, J.M.; Singhal, S.; Bhatia, B.; Keegan, D.J.; Reh, T.A.; Luthert, P.J.; Khaw, P.T.; Limb, G.A. MIO-M1 cells and similar muller glial cell lines derived from adult human retina exhibit neural stem cell characteristics. Stem Cells 2007, 25, 2033-2043. [CrossRef]

291. Bringmann, A.; Pannicke, T.; Grosche, J.; Francke, M.; Wiedemann, P.; Skatchkov, S.N.; Osborne, N.N.; Reichenbach, A. Müller cells in the healthy and diseased retina. Prog. Retin. Eye Res. 2006, 25, 397-424. [CrossRef]

292. Giannelli, S.G.; Demontis, G.C.; Pertile, G.; Rama, P.; Broccoli, V. Adult human Muller glia cells are a highly efficient source of rod photoreceptors. Stem Cells 2011, 29, 344-356. [CrossRef]

293. Jayaram, H.; Jones, M.F.; Eastlake, K.; Cottrill, P.B.; Becker, S.; Wiseman, J.; Khaw, P.T.; Limb, G.A. Transplantation of photoreceptors derived from human Muller glia restore rod function in the P23H rat. Stem Cells Transl Med. 2014, 3, 323-333. [CrossRef] [PubMed]

294. Lenkowski, J.R.; Raymond, P.A. Müller glia: Stem cells for generation and regeneration of retinal neurons in teleost fish. Prog. Retin. Eye Res. 2014, 40, 94-123. [CrossRef] [PubMed]

295. Qian, C.; Dong, B.; Wang, X.-Y.; Zhou, F.-Q. In vivo glial trans-differentiation for neuronal replacement and functional recovery in central nervous system. Febs J. 2020. [CrossRef] [PubMed]

296. Goldman, D. Müller glial cell reprogramming and retina regeneration. Nat. Rev. Neurosci. 2014, 15, 431-442. [CrossRef]

297. Wan, J.; Goldman, D. Retina regeneration in zebrafish. Curr. Opin. Genet. Dev. 2016, 40, 41-47. [CrossRef]

298. Madelaine, R.; Mourrain, P. Endogenous retinal neural stem cell reprogramming for neuronal regeneration. Neural Regen. Res. 2017, 12, 1765-1767. [CrossRef] 